\title{
Taxonomic revision of the Canthidium Erichson, 1847 species of the gigas group (Coleoptera, Scarabaeidae, Scarabaeinae)
}

\author{
Edrielly C. CARVALHO DE SANTANA ${ }^{1, *}$, Thaynara L. PACHECO ${ }^{2} \&$ \\ Fernando Z. VAZ-DE-MELLO ${ }^{3}$ \\ ${ }^{1}$ Programa de Pós-graduação em Zoologia, Instituto de Biociências, Universidade Federal de Mato \\ Grosso, Av. Fernando Correa da Costa, 2367, Boa Esperança, 78060-900, Cuiabá, MT, Brazil. \\ ${ }^{2}$ Programa de Pós-graduação em Zoologia, Instituto de Biociências, Universidade Federal de Mato \\ Grosso, Av. Fernando Correa da Costa, 2367, Boa Esperança, 78060-900, Cuiabá, MT, Brazil; \\ currently at Programa de Pós-graduação em Zoologia, Museu Nacional, Universidade Federal do Rio \\ de Janeiro, Quinta da Boa Vista, s/n, São Cristóvão, 20940-040, Rio de Janeiro, RJ, Brazil. \\ ${ }^{3}$ Departamento de Biologia e Zoologia, Instituto de Biociências, Universidade Federal de Mato \\ Grosso, Av. Fernando Correa da Costa, 2367, Boa Esperança, 78060-900, Cuiabá, MT, Brazil. \\ *Corresponding author: edrielly.carol@gmail.com \\ ${ }^{2}$ Email: thay.lpacheco@gmail.com \\ ${ }_{3}^{3}$ Email: vazdemello@gmail.com \\ ${ }^{1}$ urn:1sid:zoobank.org:author:68DA9F2A-A005-4F96-9467-03575FADF91F
${ }^{2}$ urn:1sid:zoobank.org:author:146CF81B-1394-456C-A768-BFFDE3E213D0
${ }^{3}$ urn:1sid:zoobank.org:author:82872F67-E82A-40C6-B2A3-61F262488F21
}

\begin{abstract}
The gigas species group of the subgenus Canthidium (Neocanthidium) is defined and described. This species group is composed of three described species [C. gigas Balthasar, 1939, Brazilian Atlantic Forest, including intrusions into Cerrado, C. bokermanni (Martínez et al., 1964), Chaco and western Cerrado in Brazil, Bolivia, Paraguay, and Argentina, and C. kelleri (Martínez et al., 1964), Brazilian Cerrado and neighbouring open areas] and three new species: Canthidium stofeli sp. nov. from the western and southern regions of the Brazilian Amazon, Canthidium feeri sp. nov. from French Guiana, and Canthidium ayri sp. nov. from the Brazilian Atlantic Forest. We present descriptions and redescriptions, illustrations, an identification key and comments on the distributions of the species of the gigas group.
\end{abstract}

Keywords. Dung beetles, taxonomy, new species, South America, Neotropical region.

Carvalho de Santana E.C., Pacheco T.L. \& Vaz-de-Mello F.Z. 2019. Taxonomic revision of the Canthidium Erichson, 1847 species of the gigas group. European Journal of Taxonomy 530: 1-24.

https://doi.org/10.5852/ejt.2019.530 


\section{Introduction}

The genus Canthidium Erichson, 1847 is diagnosed by the presence of nine-articulated antennae with a pubescent club; cylindrical labial palpi; ventral clypeal process usually absent, if present in the form of one longitudinal carina; mesoventrite very short; metaventrite usually simply convex; and dilation of meso and metatibia with a curved inner margin and an more or less straight outer margin in ventral view (Vaz-de-Mello et al. 2011). Canthidium is currently subdivided into two subgenera, Canthidium s. str. and Neocanthidium Martínez \& Halffter, 1986, with some species not presently assigned to any subgenus (see Cupello 2018).

Since its original description (Erichson 1847), many species have been described in general revisions (e.g., Harold 1867a, 1867b), synopses (Boucomont 1928; Balthasar 1939; Martínez et al. 1964) and regional studies (Howden \& Young 1981; Solís \& Kohlmann 2004; Kohlmann \& Solís 2006). Currently, the genus includes 170 valid species-group names (Cupello 2018; Génier \& Cupello 2018).

Due to the large number of species included in many New World dung beetle genera, efforts towards delimiting species groups that facilitate taxonomic revisions are highly desirable. So far, formal species groups have been delimited in several Scarabaeinae genera such as Dichotomius Hope, 1838 (Luederwaldt 1929; Nunes \& Vaz-de-Mello 2013), Onthophagus Latreille, 1802 (Zunino \& Halffter 1997), Eurysternus Dalman, 1824 (Génier 2009), Ontherus Erichson, 1847 (Génier 1996), and Canthon Hoffmannsegg, 1817 (Halffter \& Martínez 1977). In a preliminary attempt to discriminate some species group within Canthidium, we propose a readily distinguishable species group around Canthidium gigas Balthasar, 1939. Characters defining this group include the large size of its species in relation to the other species of the genus, strongly convex body and uniform black colour. The gigas group includes three previously described species - namely, Canthidium (N.) gigas Balthasar, 1939, C. (N.) bokermanni (Martínez et al., 1964) and C. (N.) kelleri (Martínez et al., 1964), - and three new species described below.

\section{Material and methods}

\section{Institutional abbreviations}

A total of 129 specimens were examined from the following collections:

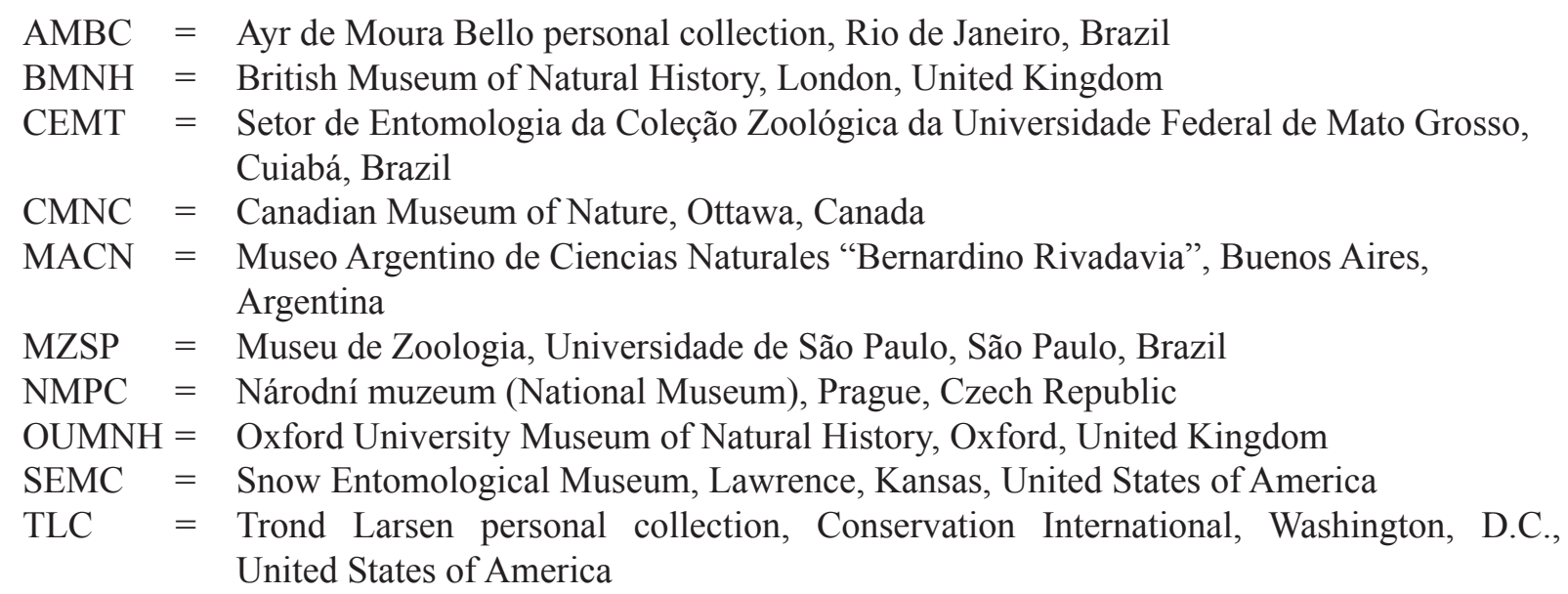

\section{Other abbreviations}

EECFA $\quad=$ Estação Experimental de Ciências Florestais Anhembi

Esalq/USP $=$ Escola Superior de Agricultura Luiz de Queiroz/Universidade de São Paulo 


$\begin{array}{ll}\text { FIT } & =\text { flight interception trap } \\ \text { PNB } & =\text { Parque Nacional de Brasilia } \\ \text { R.F. IBGE } & =\text { Instituto Brasileiro de Geografia e Estatística } \\ \text { UNESP } & =\text { Universidade Estadual Paulista } \\ \text { UNILAVRAS } & =\text { Centro Universitario de Lavras }\end{array}$

Pictures were taken using a Leica M205C stereo microscope and the images were stacked with the manufacturer's software. Maps were generated with Diva-Gis (ver. 7.5.0), using the shapefile of Löwenberg-Neto (2014) of the biogeographical regionalization of Morrone (2014). Holotype label data were transcribed verbatim in quotation marks; text lines are separated by a slash mark. The nomenclature used for the geographical distributions is based on the biogeographical regionalization scheme of Morrone (2014) . The nomenclature used for the microsculpture is based on Harris (1979).

Specimen lengths were measured from the mid-anterior part of the pronotum to the elytral apex to eliminate potential errors caused by various inclinations of the head; therefore, the length provided here is just a 'partial length', not the total length of the specimens.

\section{Results}

Class Hexapoda Blainville, 1816

Order Coleoptera Linnaeus, 1758

Family Scarabaeidae Latreille, 1802

Subfamily Scarabaeinae Latreille, 1802

Genus Canthidium Erichson, 1847

Subgenus Neocanthidium Martínez et al., 1964

\section{The gigas species group}

\section{Diagnosis}

Species of the gigas group are readily recognizable from other members of the genus by their large ( 8 to $15 \mathrm{~mm}$ ), globose black body, which contrasts with the light-coloured antennae. In addition, the group shows coarse punctation on head and anterior surface of the pronotum; dorsal surface of the eyes posteriorly narrowed; interocular distance approximately seven times wider than the maximum dorsal eye width, and clypeus with two well-defined rounded teeth separated by an acute angle.

\section{Description}

Clypeal margin well defined internally, with two more or less rounded teeth medially, separated by an acute angle. Clypeogenal suture distinct. Hypomeron with coarse longitudinal microsculpture between punctuation and obliquely-oriented setae. Prosternum with few long setae, with greater concentration at central region, the apex of each setae reaches mesoventrite. Profemora with ventral surface with a longitudinal carina along posterior margin and with a distinct row of punctures along anterior margin, each puncture with a golden seta; surface with microstriae; tibiofemoral joint with a tuft of golden setae. Protibiae widening towards apex, external edge with three teeth, external edge serrate between proximal tooth and base, dorsal surface with punctation along the central axis, anteriorly with long setae; venter with longitudinal carina and a single row of punctures parallel to lateral edge. Protibial spur tapering towards apex and more or less angulate at apical third in females or wider apically and bent ventrally at median half in males. Tarsi with five tarsomeres; claws simple, strongly curved. Mesofemora with a carina along posterior edge, ventral surface with some setae anteroapically, centre and apex with minute punctation. Mesotibiae with narrow basal half, apical half abruptly dilated, with carina and 
punctation along anterior margin, near the carina with punctation; external edge with small teeth, internal edge smooth. First mesotarsomere as long as next two mesotarsomeres combined; second to fourth mesotarsomeres decreasing gradually in length and fifth mesotarsomere longer than the fourth; claws simple and strongly curved; two apical spurs, one as long as the first mesotarsomere and the other as long as the first and second mesotarsomeres combined. Elytral striae wide and distinct, with circular punctures slightly wider than the striae. Interstriae with small, scattered punctures. Pseudepipleuron narrowing gradually towards the apex, where it dilates slightly at the end of the fifth striae; surface with sparse fine punctation. Abdomen glabrous, finely punctate. Pygidium convex, margined along posterior edge, distinctly punctate.

\section{Sexual dimorphism}

Males and females can be differentiated by the protibial spur, which has a narrow apex in females and is flattened in males.

\section{Key to the species of the gigas group}

1. Head without transverse carina, horn or tubercle along frontoclypeal suture. Cerrado-Atlantic Forest transition in São Paulo state (Brazil) .Canthidium (Neocanthidium) ayri sp. nov.

- Head with a transverse carina, conical horn or tubercle along the frontoclypeal suture 2
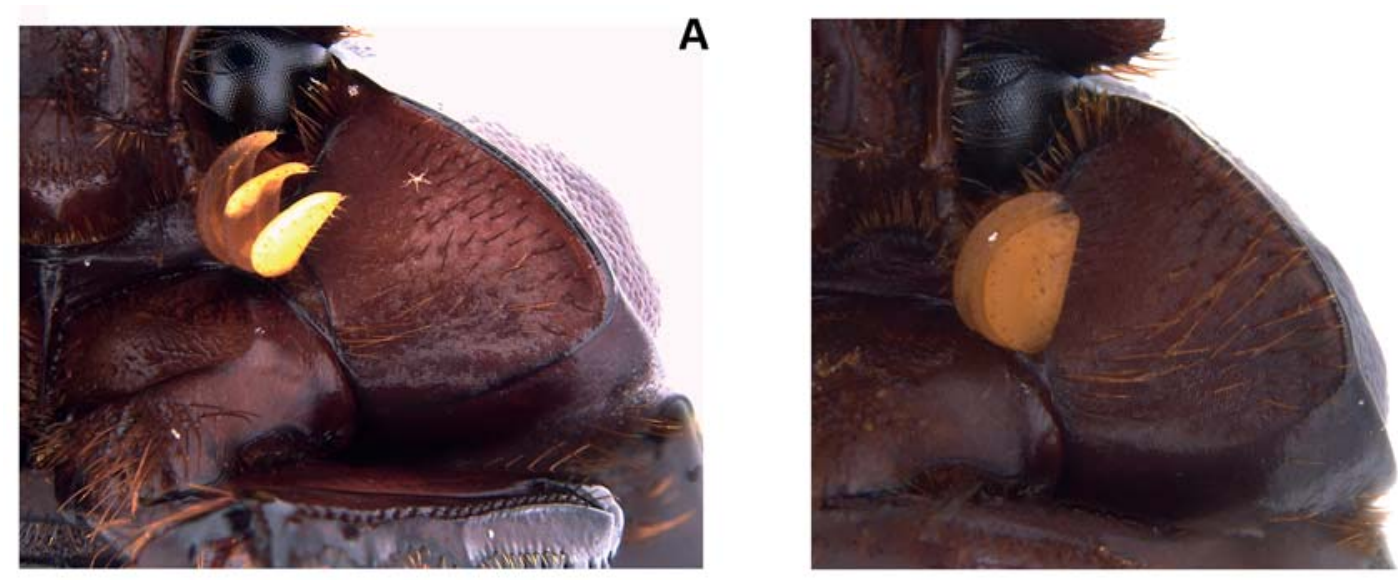

B
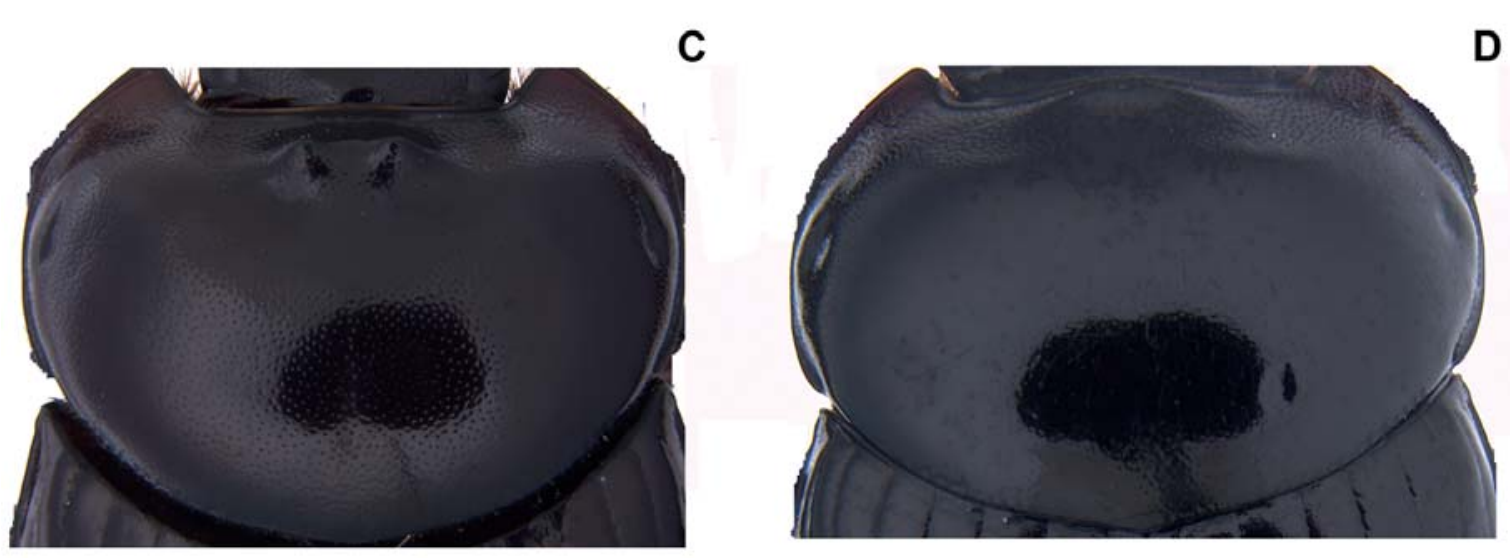

Fig. 1. A. Canthidium gigas Balthasar, 1939, hypomerum with complete hypomeral carina. B. Canthidium kelleri (Martínez et al., 1964), hypomerum with incomplete hypomeral carina. C. Disc of pronotum completely punctated. D. Disc of pronotum with indefinite punctation. Not to scale. 

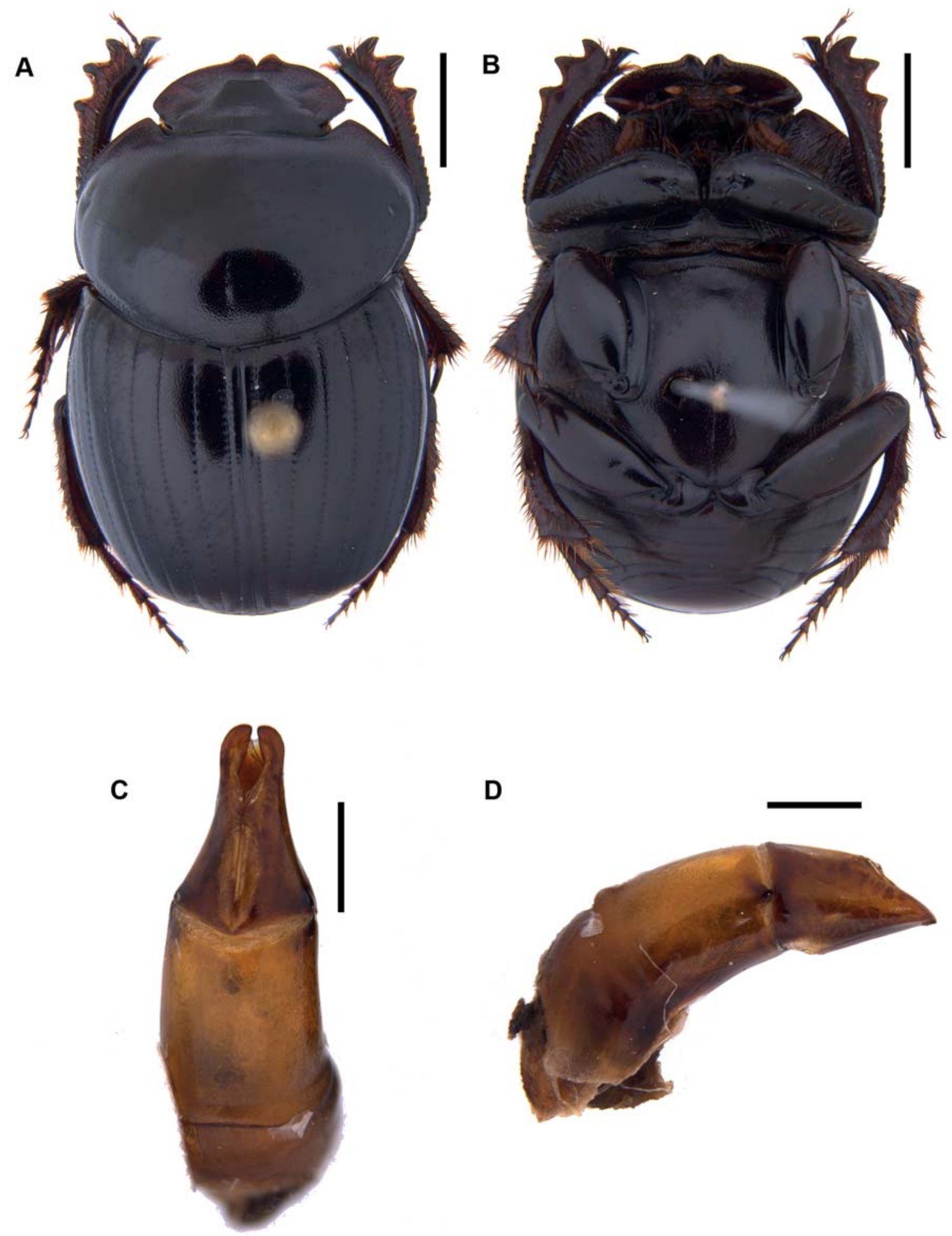

Fig. 2. Canthidium gigas Balthasar, 1939. A. Dorsal view. B. Ventral view. C. Dorsal view of aedeagus. D. Lateral view of aedeagus. Scale bars: $1 \mathrm{~mm}$. 
2. Head with conical horn. Hypomeron with incomplete hypomeral carina (Fig. 1B). Brazilian Cerrado and neighbouring open area

Canthidium (Neocanthidium) kelleri (Martínez et al., 1964)

- Head with either short or long transverse carina, lacking a horn. Hypomeron with complete hypomeral carina (Fig. 1A). Known from forested/shaded habitats

3. Head with a long transverse frontoclypeal carina, length greater than one half interocular width. Pronotum anteriorly with a shallow excavation near centre (absent in small specimens and smaller in females than in males); bordered anteriorly by a transverse bilobed carina (reduced to a pair of lobes in smaller individuals). Amazonia

- Head with a short transverse frontoclypeal carina, length less than one-third of interocular width. Pronotum convex anteriorly, without evident lobes or excavations. Chaco, Cerrado and Atlantic Forest

4. Frontoclypeal carina with length less than three-fourths of interocular width. Pronotum with anterior carina and lobes not evident, positioned just behind anterior border and separated from border by distance less than the border width; anterior region of disc punctate, posterior region with indefinite punctation (Fig. 1D). French Guiana

Canthidium (Neocanthidium) feeri sp. nov.

A

A
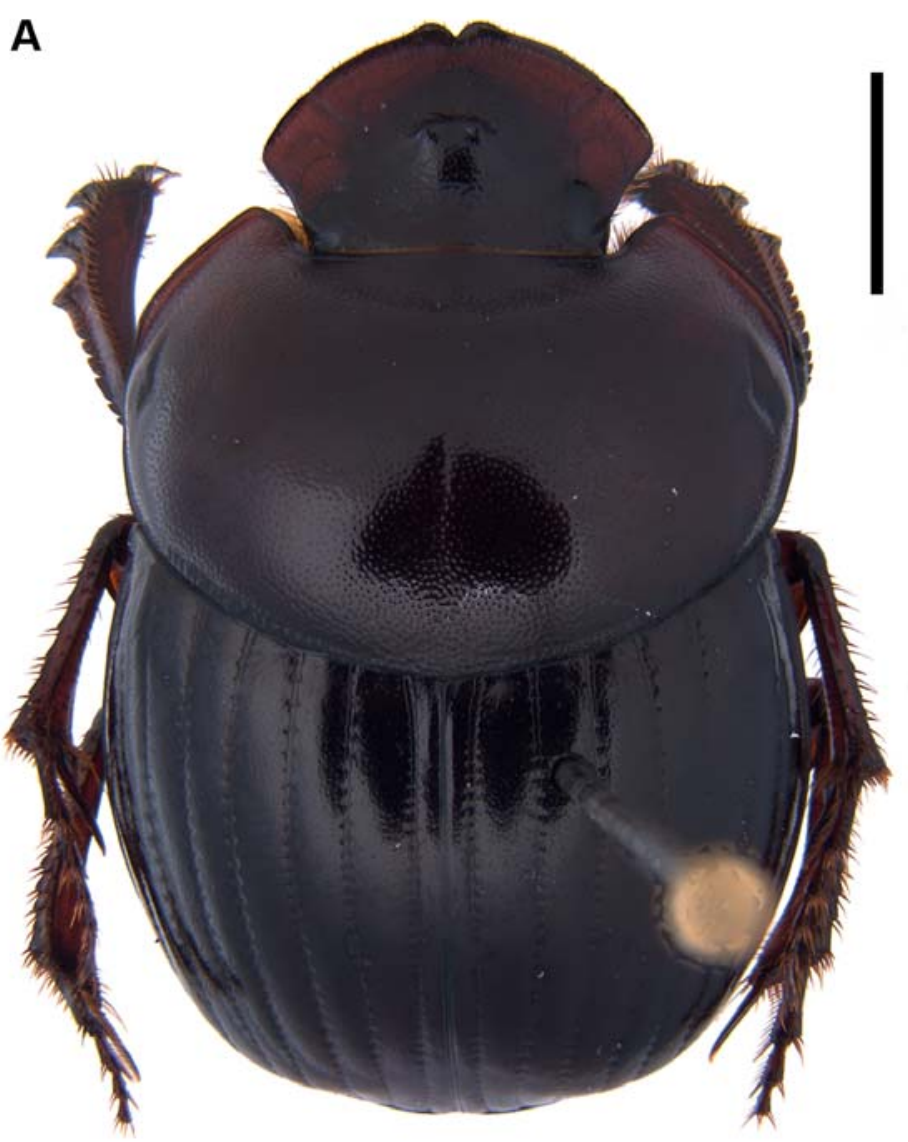

B

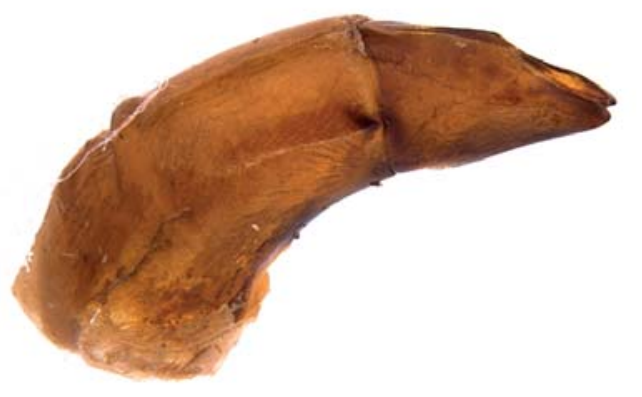

C

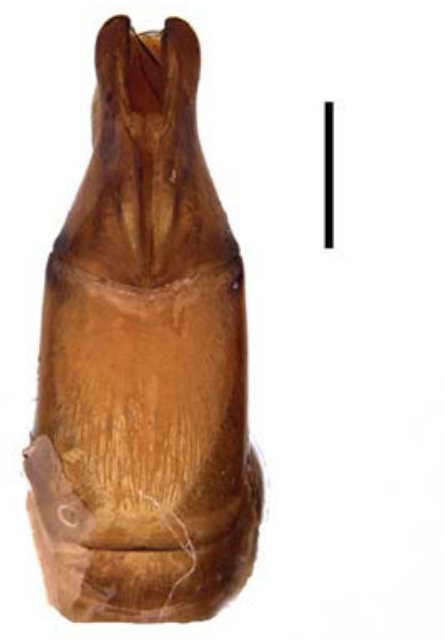

Fig. 3. Canthidium bokermanni (Martínez et al., 1964). A. Dorsal view. B. Lateral view of aedeagus. C. Dorsal view of aedeagus. Scale bars: $1 \mathrm{~mm}$. 
- Frontoclypeal carina with length greater than four-fifths of interocular width. Pronotum with both anterior carina and two lobes sharply evident, separated from border by a distance equal or greater than the latter's width; disc with surface completely punctate (Fig. 1C). Amazon rainforest south of the Amazon River in Brazil and Peru Canthidium (Neocanthidium) stofeli sp. nov.

5. Parameres, in dorsal view, with strong median angulation and concave apical excavation (Fig. 2C); in lateral view, with dorsomedial angulation of $120^{\circ}$ (Fig. 2D). Brazilian Atlantic Forest, including intrusions into Cerrado Canthidium (Neocanthidium) gigas Balthasar, 1939

- Parameres, in dorsal view, with feeble median angulation and shallow apical excavation (Fig. 3C); in lateral view, with dorsomedial angulation of $160^{\circ}$ (Fig. 3B). Chaco and western Cerrado in Brazil, Bolivia, Paraguay and Argentina

Canthidium (Neocanthidium) bokermanni (Martínez et al., 1964)

\title{
Species accounts
}

\author{
Canthidium (Neocanthidium) ayri sp. nov. \\ urn:Isid:zoobank.org:act:0209148B-40FB-43DE-8566-3EEB43646298
}

Figs 4,8

\section{Diagnosis}

Canthidium ayri sp. nov. is differentiated from the other species in the group by the unarmed head and pronotum, lacking projections.

\section{Etymology}

Named for Ayr de Moura Bello, great collector and enthusiast of Brazilian beetles, directly or indirectly responsible for the present increase of studies on Brazilian Coleoptera.

\section{Type material}

\section{Holotype}

BRAZIL • ô; “Cerqueira César/ SP-Brasil/ II-1995/ COL. J. Carlos”; CEMT, ex AMBC.

\section{Paratypes}

BRAZIL - São Paulo • 1 क ; Anhembi; EECFA, Esalq/USP; light trap, Eucalyptus urophylla; $22^{\circ} 40^{\prime}$ S, $48^{\circ} 10^{\prime}$ W; E.N.L. Ferreira leg.; CEMT. - Paraná • 1 o; Icaraima, Estância Felipe; same collection data as for preceding; 23 Dec. 2018-5 Jan. 2019; D.F. Rodrigues leg.; CEMT. - Minas Gerais • 1 ऽ;;

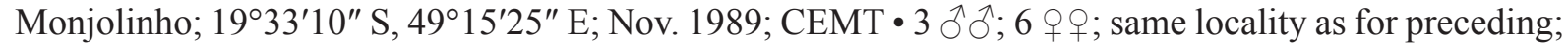

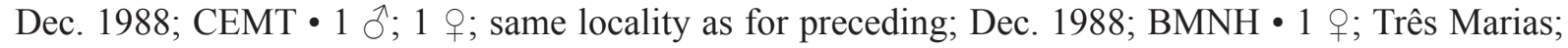
$18^{\circ} 12^{\prime 2} 23^{\prime \prime} \mathrm{S}, 45^{\circ} 13^{\prime} 53^{\prime \prime}$ E; Nov. 1989; CEMT • 1 क; same locality as for preceding; Nov. 1991; J.C. Zanúncio leg.; CEMT.

\section{Description (holotype)}

MEASUREMEnTs. Length: $8 \mathrm{~mm}$.

HEAD. Surface with microsculpture obscurely variolate. Without frontoclypeal carina.

Pronotum. Regularly convex, strongly and completely punctate, without projections along anterior margin.

Hypomeron. Hypomeral carina complete. 
MetaVentrite. With simple and shallow punctation, laterobasal region with stronger punctation, lateral region with microsculpture obscurely variolate, almost semicircular.

MESEPIMERON AND MESEPISTERNUM. With shallow punctation, stronger microsculpture obscurely variolate, almost semicircular.

HIND LEG. Metafemora with a carina along posterior edge, anterior edge with setal fringe, surface with fine punctation. Metatibiae elongated and gradually dilated towards the apex; external margin serrated.

AedeAgus. In dorsal view, parameres with median angulation nearly absent and with a shallow apical cavity; in lateral view, with dorsal angulation at the basal one-third.

\section{Variation and sexual dimorphism}

Length ranging from 8.00 to $8.31 \mathrm{~mm}$. Males with ventrite VI wider medially, female ventrite VI with the same length throughout. Males also have protibial spur flattened, while in females the protibial spur is narrowed and pointed.

\section{Geographical distribution}

The specimens examined were collected in the Brazilian state of São Paulo in the Paraná and Chacoan dominion.

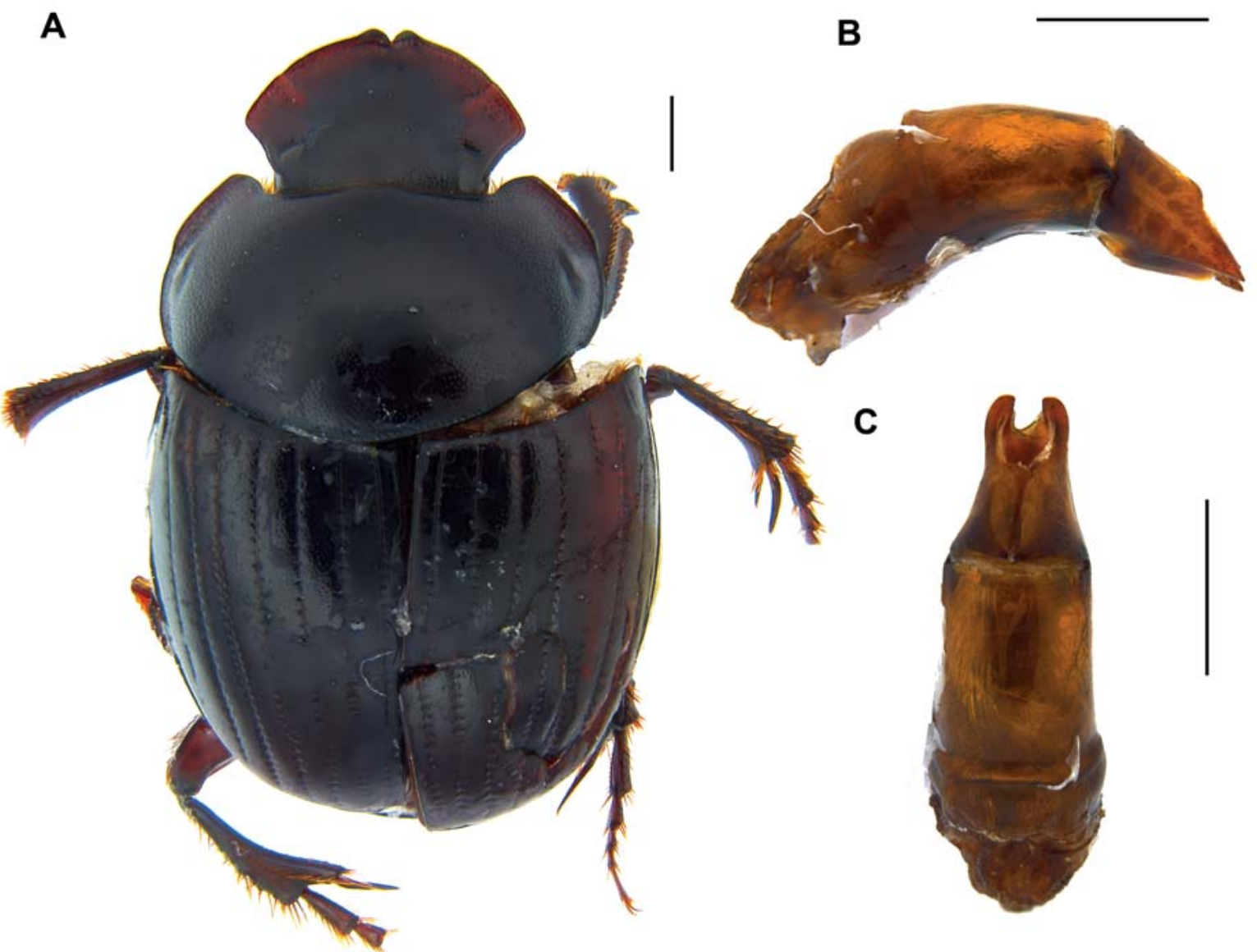

Fig. 4. Canthidium ayri sp. nov., holotype (CEMT) A. Dorsal view. B. Lateral view of aedeagus. C. Dorsal view of aedeagus. Scale bars: $1 \mathrm{~mm}$. 
Canthidium (Neocanthidium) kelleri (Martínez et al., 1964)

Figs 1B, 5, 8

Neocanthidium kelleri Martínez et al., 1964: 172-177 (original description).

Dichotomius (Luederwaldtinia) paraguayanus Gandini \& Aguilar, 2009: 139, figs 1-8 (original description) (synonymized by Nunes \& Vaz-de-Mello 2013: 416).

Canthidium (Canthidium) kelleri - Martínez \& Halffter 1986: 28 (new combination). — Vaz-de-Mello 2000: 191 (checklist). — Nunes \& Vaz-de-Mello 2013: 416 (senior synonymy).

Canthidium (Neocanthidium) kelleri - Cupello 2018: 470 (new subgeneric assignment).

\section{Diagnosis}

Canthidium kelleri differs from other species of the gigas group by the presence of a conical projection on the head which varies in development according to the size of the specimen.

\section{Type specimens examined}

\section{Neocanthidium kelleri}

\section{Holotype}

ARGENTINA • o ; handwritten label; "ARGENTINA/ MISSIONES/ LORETO/ En mongas him./ Coll. Martínez// Enc: 958"; "HOLOTYPUS"; "Neocanthidium/ kelleri sp. n. §̋/ M., H y P./ A. MARTÍNEZ DET.1963”; "MACN-En 1223”; MACN.

\section{Dichotomius paraguayanus}

\section{Holotype}

PARAGUAY - O'; "PARAGUAY: Concepcion, Zanja Moroti. 2.xi.2004"; originally in Gandini's collection, now deposited in CEMT; CEMT.

\section{Paratypes}

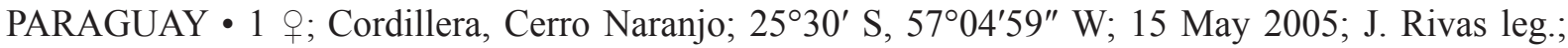
CEMT.

\section{Other specimens examined}

BRAZIL • 1 9; Distrito Federal, Brasília; 1547'39.22" S, 4752'55.81" W; R.F. IBGE; Dec.1997; I. Diniz leg.; CEMT • 1 क ; Brasília, Fazenda Água Limpa; 1557'11.05" S, 4758'23.76" W; 16 Sep. 1979;

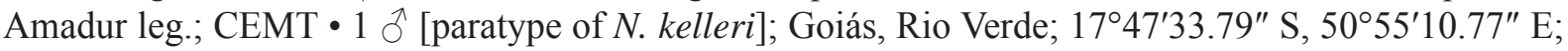
Dr. Nick leg.; CEMT • 1 क; Mato Grosso, Cuiabá, Fazenda [“Faz.”] Mutuca, Eucalipto-5; 15¹8'51" S,

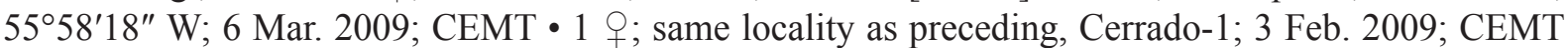
- $1 \mathrm{O}^{\top}$; Chapada dos Guimarães, Cachoeira da Geladeira; FIT; $15^{\circ} 25^{\prime} 25^{\prime \prime} \mathrm{S}, 55^{\circ} 42^{\prime} 58^{\prime \prime} \mathrm{W}$; 6,200 m a.s.l.; 9-30 Jan. 2013; D. Gimo leg.; CEMT • 1 q; same locality as for preceding, Comunidade João

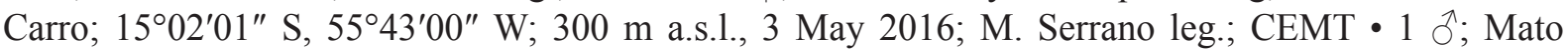
Grosso do Sul; Selvíria, UNESP farm, Brachiaria decumbens pasture; black light trap; $20^{\circ} 25^{\prime} 6.82^{\prime \prime}$ S, 51 ${ }^{\circ} 20^{\prime} 51.87^{\prime \prime}$ W; 21 Sep. 2000; C.A.H. Flechtmann leg.; CEMT • 1 q; Minas Gerais, Cordisburgo,

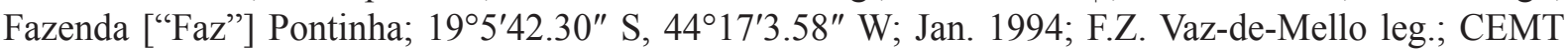
- 1 J ; same locality as for preceding; Jan. 1999; Falqueto and Vaz-de-Mello leg.; BMNH • 1 q; same data as for preceding; CEMT • 1 क ; Uberaba; $19^{\circ} 44^{\prime} 50.52^{\prime \prime}$ S, 47 $56^{\prime} 20.95^{\prime \prime} \mathrm{W}$; CEMT • 1 q; Lavras;

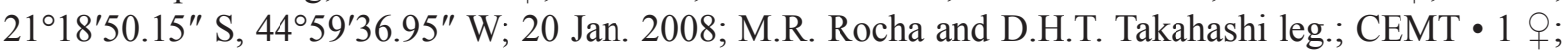

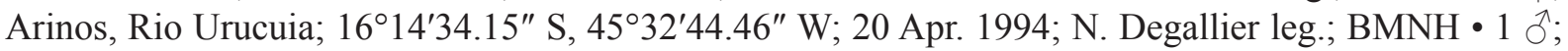
Buritis, Fazenda ["Faz"] Querência; FIT; 15¹0'23,5" S, 46³2'43,1" W; 978 m a.s.l.; 10 Jul. 2013-4 Feb. 2014; C.M. Oliveira leg.; CEMT. 


\section{Redescription}

HEAD. Surface densely and distinctly punctated, especially on the clypeus. Frontoclypeal suture with conical projection.

Pronotum. Regularly convex, without projections, sometimes excavated anteriorly. Anterior edge slightly curved, sides arched.

Hypomeron. Hypomeral carina incomplete.

METAVENTRITE. With simple and shallow punctation, laterobasal region with stronger punctation, lateral region with microsculpture obscurely variolate, almost semicircular.

MESEPIMERON AND MESEPISTERNUM. With shallow punctation, stronger microsculpture obscurely variolate, almost semicircular.

HIND LEG. Metafemora with a carina along posterior edge, anterior edge with setal fringe, surface with fine punctuation. Metatibiae elongated and gradually dilated towards the apex; external margin serrated.

Aedeagus. Parameres, in lateral view, with dorsal angulation at basal two-fifths.

\section{Variation and sexual dimorphism}

Length ranging from 8.95 to $11.54 \mathrm{~mm}$. Smaller specimens have the frontal horn reduced in size, appearing as a transverse gibbosity. Pronotum with the anteromedial depression less visible and shallower in some
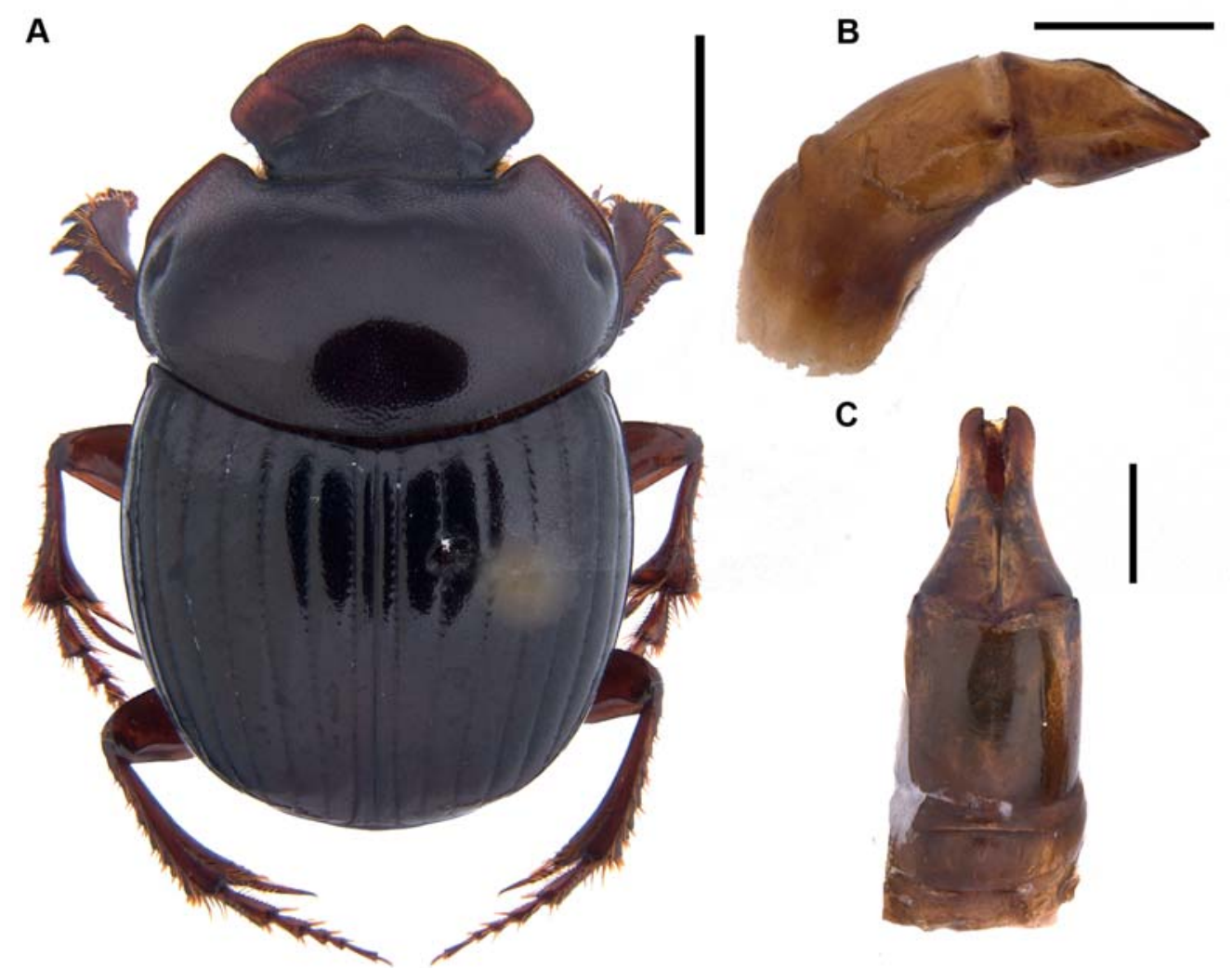

Fig. 5. Canthidium kelleri (Martínez et al., 1964). A. Dorsal view. B. Lateral view of aedeagus. C. Dorsal view of aedeagus. Scale bars: $1 \mathrm{~mm}$. 
specimens. Pygidium slightly less convex if compared with C. bokermanni. Males present a small tooth in the upper ventral part of their metatibiae. Males with ventrite VI wider medially, female ventrite VI with the same length throughout. Males also have protibial spur flattened, while in females the protibial spur is narrowed and pointed.

\section{Geographical distribution}

The specimens examined were collected in Paraguay (Cordillera) and Brazil (Mato Grosso, Mato Grosso do Sul, Goiás, Distrito Federal and Minas Gerais). It is present in the Cerrado and the Chaco biomes, which lie in the Chacoan dominion.

\section{Comments}

The holotype and one paratype originally identified as male of $D$. paraguayanus were examined by us and were shown to be C. kelleri, thus confirming the name's synonymy with C. kelleri as firstly proposed by Nunes \& Vaz-de-Mello (2013). However, two paratypes originally said to be females by Gandini \& Aguilar (2009) are actually males, and belong to C. bokermanni. See comments below.

\section{Canthidium (Neocanthidium) feeri sp. nov. urn:1sid:zoobank.org:act:EFF5685C-71C4-434D-9A9F-9431B46B0B36}

Figs 1D, 6, 9

\section{Diagnosis}

Canthidium feeri sp. nov. differs from other species of the group by the distinct anterior pronotal punctation, apparently lacking punctures on the centre of the disc.

\section{Etymology}

Named for François Feer, French scarabaeidologist, working at the Muséum national d'Histoire naturelle (Paris, France) who collected half of the type series.

\section{Type material}

\section{Holotype}

FRENCH GUIANA - ô; "GUYANE FRANÇAISE: St/ Laurent du Maroni, Bélvédère/ de Saul, 03³7'22" S/ 5312'57" W, 17.i.2011”; “22363”; CEMT.

\section{Paratypes}

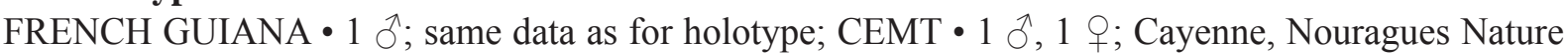

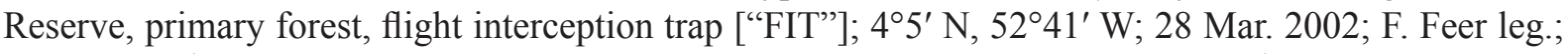

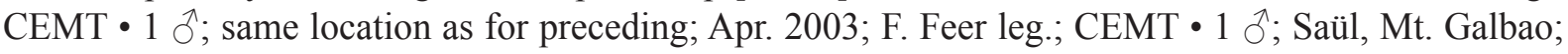
ex. flight int. trap; $3^{\circ} 37^{\prime} 18^{\prime \prime}$ N 53 $3^{\circ} 16^{\prime} 42^{\prime \prime}$ N; 740 m a.s.1.; 5-7 Jun. 1997; J. Ashe and R. Brooks leg.; FG1AB97; \#154; CMNC.

\section{Type locality}

Bélvédère de Saül, Saint-Laurent-du-Maroni, French Guiana, France.

\section{Description (holotype)}

MeAsurements. Length: $9 \mathrm{~mm}$.

HEAD. Surface dense and distinctly punctated. Frontoclypeal carina rectangular and with length less than three-fourths of interocular distance. 
Pronotum. With anterior carina and lobes not evident, positioned just behind anterior border and separated from border by distance less than the border width; anterior region of disc punctated, posterior region with indefinite punctation.

HYPOMERON. Hypomeral carina complete.

Metaventrite. With simple and shallow punctation, laterobasal and lateral region with microsculpture finely strigulate.

MeSEPIMEROn AND MESEPISTERnUm. With shallow punctation and microsculpture finely strigulate.

HIND LEG. Metafemora with a carina along posterior edge, anterior edge with setal fringe, surface with fine punctation. Metatibiae elongated and gradually dilated towards the apex; external margin serrated.

AedEAgus. Parameres, in lateral view, dorsally with angulation on basal third.

\section{Variation and sexual dimorphism}

Total length ranging from 9.00 to $10.67 \mathrm{~mm}$. Some males present a small tooth in the upper ventral part of their metatibiae and some have a protuberance on their basal half. Males with ventrite VI wider
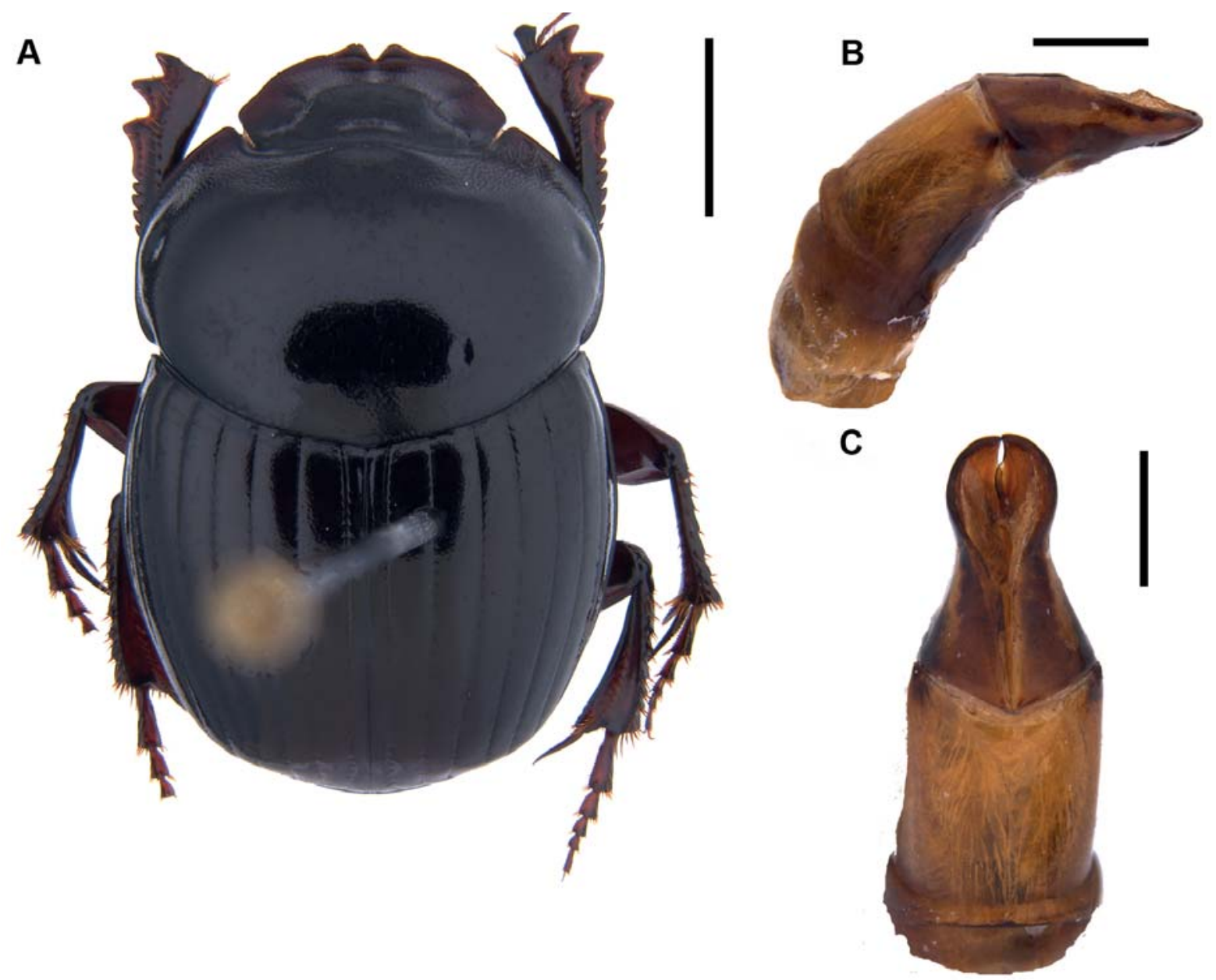

Fig. 6. Canthidium feeri sp. nov., holotype (CEMT) A. Dorsal view. B. Lateral view of aedeagus. C. Dorsal view of aedeagus. Scale bars: $1 \mathrm{~mm}$. 
medially, female ventrite VI with the same length throughout. Males also have protibial spur flattened, while in females the protibial spur is narrowed and pointed.

\section{Geographical distribution}

All the specimens examined for this work were collected in French Guiana, which is located in the Boreal Brazilian dominion.

\section{Canthidium (Neocanthidium) stofeli sp. nov. urn:1sid:zoobank.org:act:1A3F5B17-8091-4ACC-B7DE-4311ADA3400D}

Figs 7,9

\section{Diagnosis}

Canthidium stofeli sp. nov. differs from the other species in the group by having two anterior medial projections, one on each side of the pronotum.

\section{Etymology}

Named after Roberto Stofel, for the field support during collections in Cotriguaçu.

\section{Type material}

\section{Holotype}

BRAZIL • ô; "BRASIL: Rondônia: Guajará/ Mirim: Proprietário: Fandinho/ 1044'57.62" S, 651'0.32" W/ 138m. flor. Amaz. Isca: baço bov/ 24.II.2010 F.Coletti”; “22366”; CEMT.

\section{Paratypes}

BRAZIL - 1 ơ; Acre, Rio Branco, Fazenda [“Faz”] Catuaba; 957'19.77" S, 6551'55.72" W; Feb. 1997; F. Vaz-de-Mello leg.; CEMT • 1 \&; Rondônia, Guajará-Mirim, Sítio Coletti; flight interception trap ["FIT"]; 10¹9'47.11" S, 445'12.5" W; 170 m a.s.1.; 28 Jan. 2010; F. Coletti leg.; CEMT • 1 क; Pará, Tailândia, Empresa Agropalma; 9-16 Jul. 2016; P. Silva leg.; CEMT • 1 क; Belterra, forest; hum/ pig trap; 317'47" S, 545'ㄴ" W; 132 m a.s.1.; 24 Mar. 2017; F. França leg.; T2P3; CEMT • 1 q; same locality as for preceding; T15P20; CEMT • 1 क; Mato Grosso, Querência, Fazenda São Luiz, Amazon

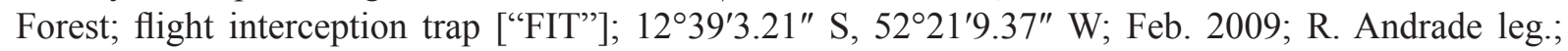

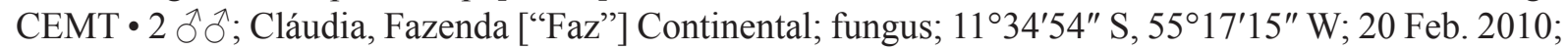

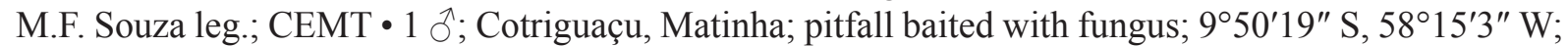
11-13 Jul. 2009; F.Z. Vaz-de-Mello leg.; BMNH • 1 đ; same data as for preceding; CEMT $\bullet 2$ 우; Cotriguaçu, Fazenda ["Faz"] São Nicolau; flight interception trap ["FIT”]; 949'9" S, 58¹5'47" W; 12-14 Jul. 2009; F.Z. Vaz-de-Mello leg.; CEMT • 1 क; same data as for preceding; BMNH • 1 '; Cotriguaçu, Fazenda ["Faz"] São Nicolau; pitfall baited with fungus; 9 $49^{\prime} 8^{\prime \prime}$ S, 58 $8^{\circ} 15^{\prime} 40^{\prime \prime}$ W; 17-21 May 2012; F.Z. Vaz-de-Mello leg.; CEMT • 1 §; Cotriguaçu, Fazenda [“Faz"] São Nicolau, primary forest; flight interception trap ["FIT"]; 9 $50^{\prime} 24^{\prime \prime}$ S, 58 $8^{\circ} 15^{\prime} 10^{\prime \prime}$ W; 250 m a.s.1.; 6 May 2009; Vaz-deMello leg.; CEMT • 1 ภิ, 1 \%; Fazenda São Nicolau (site 6), primary forest; flight int. trap; $9^{\circ} 49^{\prime} 16^{\prime \prime}$ S, 58 $15^{\prime} 33^{\prime \prime}$ W; 220 m a.s.1.; 1 Dec. 2013; F. Génier leg.; CMNC 2013-118 • 1 क; Fazenda São Nicolau

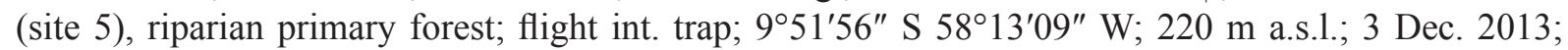
F. Génier leg.; CMNC 2013-129 • 1 क; Fazenda São Nicolau (site 6), primary forest; flight int. trap; 949'16" S, 58 $15^{\prime} 33^{\prime \prime}$ W; 220 m a.s.1.; 3 Dec. 2013; F. Génier leg.; CMNC 2013-131.

PERU • 1 क; Madre de Dios, CICRA Los Amigos B.S; 12³4'1" S, 7006'0" W; 250 m a.s.1.; 2005; T. Larsen leg.; TLC 1 o; CICRA Field Station, trail 6, research plot; blue pan trap; $12.55207^{\circ} \mathrm{S}$, 70.10962 ${ }^{\circ}$ W; 295 m a.s.l.; 7-9 Jun. 2011; Chaboo team leg.; SEMC PER-11-PTB-009 • 1 q; Rio Tambopata, Jorge Chavez; flight intercept trap; $12^{\circ} 38^{\prime} 59^{\prime \prime}$ S, 6906'24" W, 230 m a.s.1.; 28-29 Sep. 1999; 
T. Larsen leg.; CMNC • 1 \%; Rio Palma Real Grande, Limon Camp; flight intercept trap; $12^{\circ} 32^{\prime} 20^{\prime \prime} \mathrm{S}$, 68 51'40" W; 220 m a.s.1.; 9-10 Oct. 1999; T. Larsen leg.; CMNC • 1 O; Rio Palma Real Grande, Limon Camp; flight intercept trap; 12³2'20" S, 68 51'40" W; 220 m a.s.1.; 13-14 Oct. 1999; T. Larsen leg.; CMNC.

\section{Type locality}

Guajará-Mirim, Rondônia, Brazil.

\section{Description (holotype)}

Measurements. Length: $10 \mathrm{~mm}$.

HEAD. Surface densely and distinctly punctated; with rectangular frontoclypeal carina, length greater than four-fifths of the interocular distance.

Pronotum. Completely punctate, with dense and distinct punctation, becoming more accentuated towards the centre of the disc, regularly convex with two medial projections anteriorly, one on each side.

Hypomeron. Hypomeral carina slightly curved toward edge.
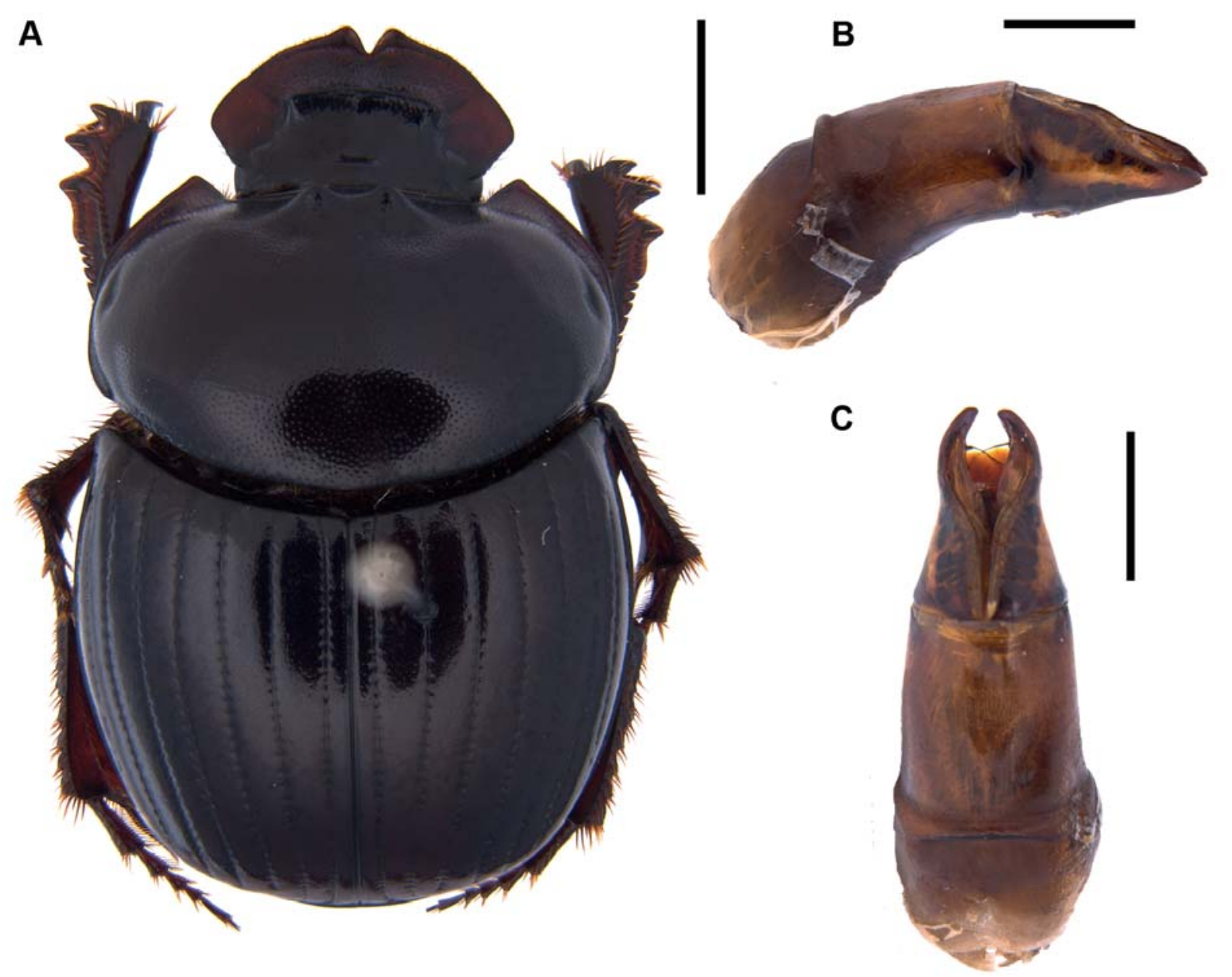

Fig. 7. Canthidium stofeli sp. nov., holotype (CEMT) A. Dorsal view. B. Lateral view of aedeagus. C. Dorsal view of aedeagus. Scale bars: $1 \mathrm{~mm}$. 
Metaventrite. With simple and shallow punctation, laterobasal region with stronger punctation, lateral region with microsculpture obscurely variolate, almost semicircular.

MESEPIMERON AND MESEPISTERNUM. With shallow punctation, stronger microsculpture obscurely variolate, almost semicircular.

HIND LEG. Metafemora with a carina along posterior edge, anterior edge with setal fringe, surface with fine punctation. Metatibiae elongated and gradually dilated towards the apex; external margin serrated.

AedeAgus. In dorsal view, parameres with a strong concave angulation and abruptly curved apex.

\section{Variation and sexual dimorphism}

Length ranging from 8.87 to $11.11 \mathrm{~mm}$. The projections on the pronotal disc vary according to the size of the specimen, being allometrically developed as the size of the body increases. Males with ventrite VI wider medially, female ventrite VI with the same length throughout. Males also have protibial spur flattened, while in females the protibial spur is narrowed and pointed.

\section{Geographic distribution}

The specimens examined came from Brazil (Mato Grosso, Rondônia, Pará) and Peru (Madre de Dios). The species occurs in the southern region of the Amazon biome, corresponding to the Southeastern Amazonian dominion and Boreal Brazilian dominion.

\section{Canthidium (Neocanthidium) gigas Balthasar, 1939}

Figs 1.A, C, 2, 10

Canthidium gigas Balthasar, 1939: 127, 128 (original description)

Canthidium gigas - Martínez 1947: 111 (checklist).

Canthidium (Canthidium) gigas - Martínez \& Halffter 1986: 27 (checklist).

Canthidium (Neocanthidium) gigas - Cupello 2018: 469 (new subgeneric assignment).

Neocanthidium gigas - Vulcano \& Pereira 1964: 592 (identification key).

\section{Type material}

\section{Holotype}

BRAZIL • O; handwritten label; "Cayenne"; "Coll C Felsche/ Kauf 20, 1918”; "C. gigas/ sp. m./ Dr. V. Balthasar det."; "gigas/ m."; "TYPUS"; "HOLOTYPE O"; NMPC.

\section{Other specimens examined}

BRAZIL • 1 +; Espírito Santo, Domingos Martins, Parque Estadual ["P.E."] Pedra Azul; 20²3'19.93" S,

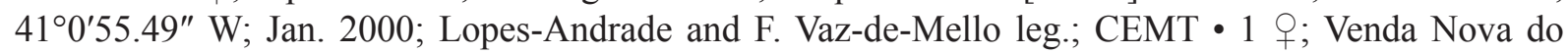
Imigrante; $20^{\circ} 19^{\prime} 39.02^{\prime \prime} \mathrm{S}, 41^{\circ} 8^{\prime} 9.36^{\prime \prime} \mathrm{W}$; Feb. 1998; Falqueto and Vaz-de-Mello leg.; CEMT • 1 \%; Rio

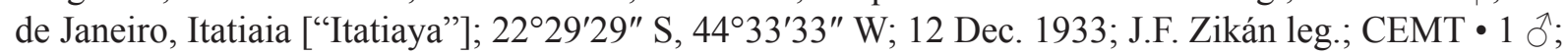

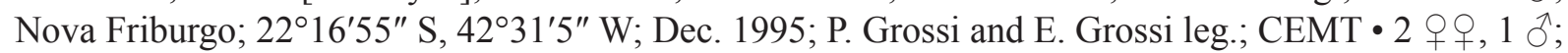
Nova Friburgo; Nov. 2001; E. Grossi leg.; AMBC • 1 क; Nova Friburgo, Macaé de Cima; $22^{\circ} 24^{\prime} 8.45^{\prime \prime}$ S, 42॰30'48.39" W; Jan. 1999; P. Grossi leg.; CEMT • 1 +; same locality as for preceding; Mar. 2000; Vazde-Mello leg.; CEMT • 1 क; same locality as for preceding; Dec. 2001; E. and P. Grossi leg.; CEMT

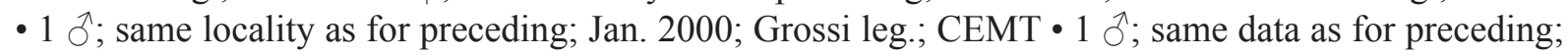
BMNH • 1 Ō; Rio de Janeiro, Corcovado; Dec. 1959; M. Alvarenga leg.; MZSP • 1 +; São Paulo, São Luiz do Paraitinga, Parque Estadual da [“Pq. Est."] Serra do Mar, Núcleo Santa Virgínia; Nov. 2004; M. Uehara leg.; AMBC • 1 क; Minas Gerais, Ingaí, Reserva do Boqueirão, UNILAVRAS, gallery forest; 
flight interception trap [“FIT"]; 21 ${ }^{\circ} 31^{\prime} 08.05^{\prime \prime} \mathrm{S}, 4^{\circ} 55^{\prime} 39.81^{\prime \prime} \mathrm{E} ; 13$ Nov. 2002; Silva and Frieiro-Costa

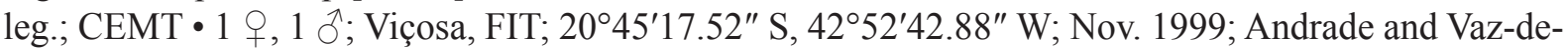
Mello leg.; CEMT • 1 क; same data as for preceding; BMNH $\bullet 1$ क; same locality as for preceding; Jan. 1999; Vaz-de-Mello leg.; CEMT • 3 우, 1 ○े; same locality as for preceding; Nov. 1998; Vaz-de-Mello leg.; CEMT • 1 '; same locality as for preceding; Universidade Federal de Viçosa; FIT; 20 45'51.99" S, 4252'5.68" W; Mar. 1998; Vaz-de-Mello leg.; CEMT • 1 ô; Viçosa, Mata da Biologia; 2045' S, $42^{\circ} 51^{\prime}$ W; Nov. 2000; F.Z. Vaz-de-Mello leg.; CEMT • 2 우; same locality as for preceding; Mata do Paraíso; Dec. 2000; Vaz-de-Mello leg.; CEMT • 1 \%; same locality as preceding; Dec. 1998; Falqueto and

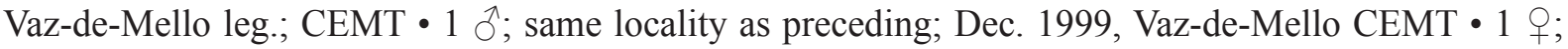
same locality as for preceding, FIT; 13 Feb. 2015; S. Aloquio, A. Orsetti, C. Lopes-Andrade and M.

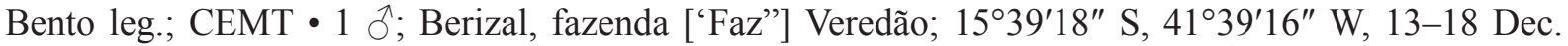
2012; P. Grossi leg.; CEMT • 1 क; Distrito Federal, Brasília, FAL-UNB ["Faz Água Limpa"], gallery

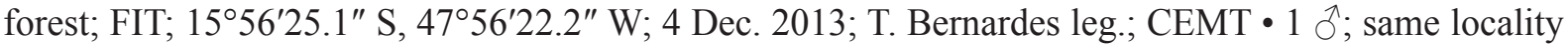
as for preceding; PNB, gallery forest, FIT; $14^{\circ} 44^{\prime} 49,5^{\prime \prime} \mathrm{S}, 48^{\circ} 00^{\prime} 32,3^{\prime \prime} \mathrm{W} ; 11$ Nov. 2015; N.H.D.Silva leg.; CEMT • 1 ○ं; same locality as for preceding; 21 Dec. 2015; N.H.D. Silva leg.; CEMT • 1 q; same locality as for preceding; 27 Nov. 2015; N.H.D. Silva leg.; CEMT 1 $\$$; same locality as for preceding; 12 Jan. 2016; N.H.D.Silva leg.; CEMT • 1 क; Paraná, Campina Grande do Sul, Estrada da mandaçaia; FIT; 2517'54" S, 4902'30" W; 7-10 Apr. 2014; F.W.T. Leivas leg.; CEMT.

\section{Diagnosis}

Canthidium gigas resembles C. bokermanni in the presence of a transverse carina on the head and distinct punctation on the pronotal disc. They differ only in the dorsal curvature of the parameres. In C. gigas, in dorsal view, the parameres have a strong angulation on their apical half and bear a concave medial excavation from the middle to the apex; in lateral view, the parameres have a dorsal angulation

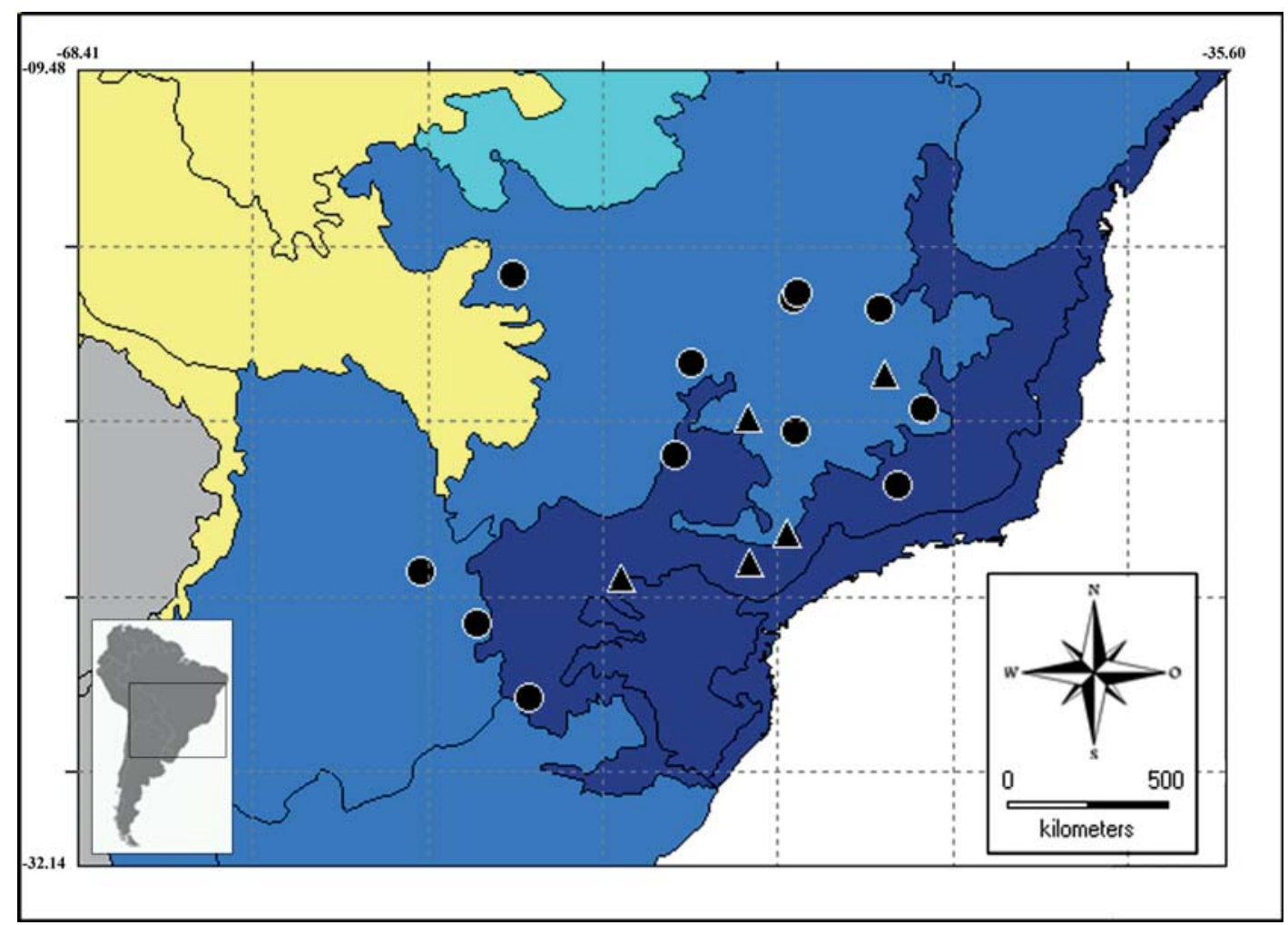

Fig. 8. Geographical distribution of Canthidium kelleri (Martínez et al., 1964) (circles) and Canthidium ayri sp. nov. (triangles). 
of $120^{\circ}$. In C. bokermanni, in dorsal view, the apical angulation is almost absent and there is a shallow medial excavation at the apex; in lateral view, the parameres have a dorsal internal angulation of $160^{\circ}$.

\section{Type locality}

Brazilian Atlantic Forest. Originally said to be Cayenne, French Guiana, but this is an error. See geographic distribution below.

\section{Redescription}

HEAD. Surface with dense and distinct punctation, particularly on clypeus. With a transverse raised projection in the front.

Pronotum. Without anteromedial depression, disc anteriorly convex, sometimes with an anterior sinuosity forming two broad and shallow depressions (both surrounding the medial line). Surface with dense and distinct punctation, attenuating towards the centre of disc, where punctation is fine and sparse.

Hypomeron. With microstriae and setae in the basal part. Hypomeral carina complete curved throughout its length.

MetaventRite. With simple and shallow punctation, laterobasal region with stronger punctation, lateral region with microsculpture obscurely variolate, almost semicircular.

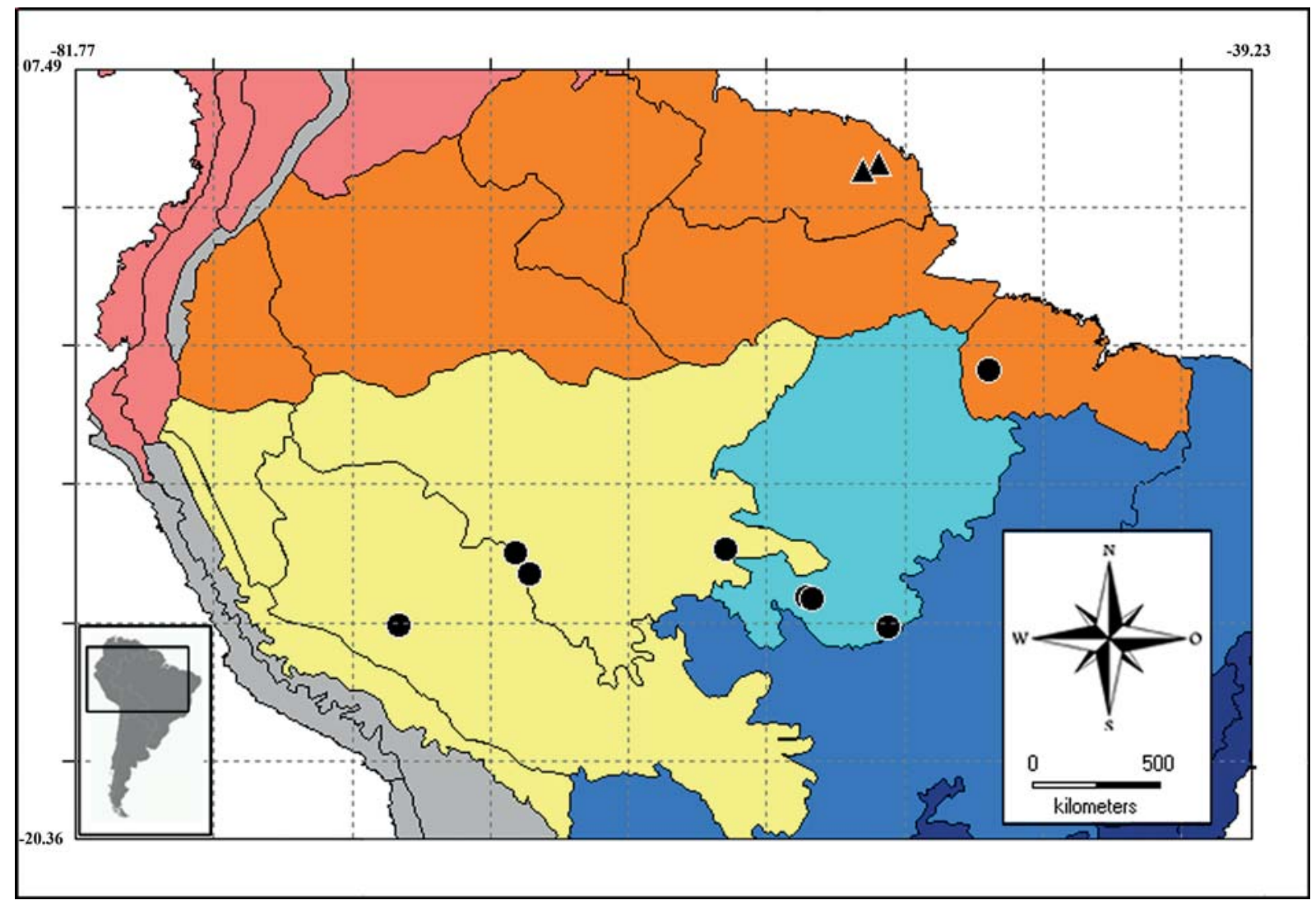

Fig. 9. Geographical distribution of Canthidium stofeli sp. nov. (circles) and Canthidium feeri sp. nov. (triangles).. 
MESEPIMERON AND MESEPISTERNUM. With shallow punctation, stronger microsculpture obscurely variolate, almost semicircular.

HIND LEG. Metafemora with a carina along posterior edge, anterior edge with setal fringe, surface with fine punctation. Metatibiae elongated and gradually dilated towards the apex presenting a sinuosity; external margin serrated.

AEDEAGUS. In dorsal view, parameres with a strong angulation in apical half and with a concave excavation from the middle to the apex; in lateral view, with internal medial angulation of $120^{\circ}$ dorsally.

\section{Variations and sexual dimorphism}

Length ranging from 9.40 to $12.65 \mathrm{~mm}$. Transverse projection of head sometimes not well defined. The males have a tooth in the upper ventral part, more developed in some specimens than in others. Males with ventrite VI wider medially, female ventrite VI of the same length throughout. Males also have protibial spur flattened, while in females the protibial spur is narrowed and pointed.

\section{Geographical distribution}

The specimens examined were mostly collected in the Brazilian states of Minas Gerais, São Paulo, Espírito Santo and Paraná in the Atlantic rainforest biome, located in the Paraná dominion. The record from Distrito Federal is surprising for the species. Judging from the rest of the known distribution, its presence there may be due to gallery forest connecting it to the Atlantic Forest on the coast. Although the holotype is labelled as coming from French Guiana, we believe this represents a mislabelling, since

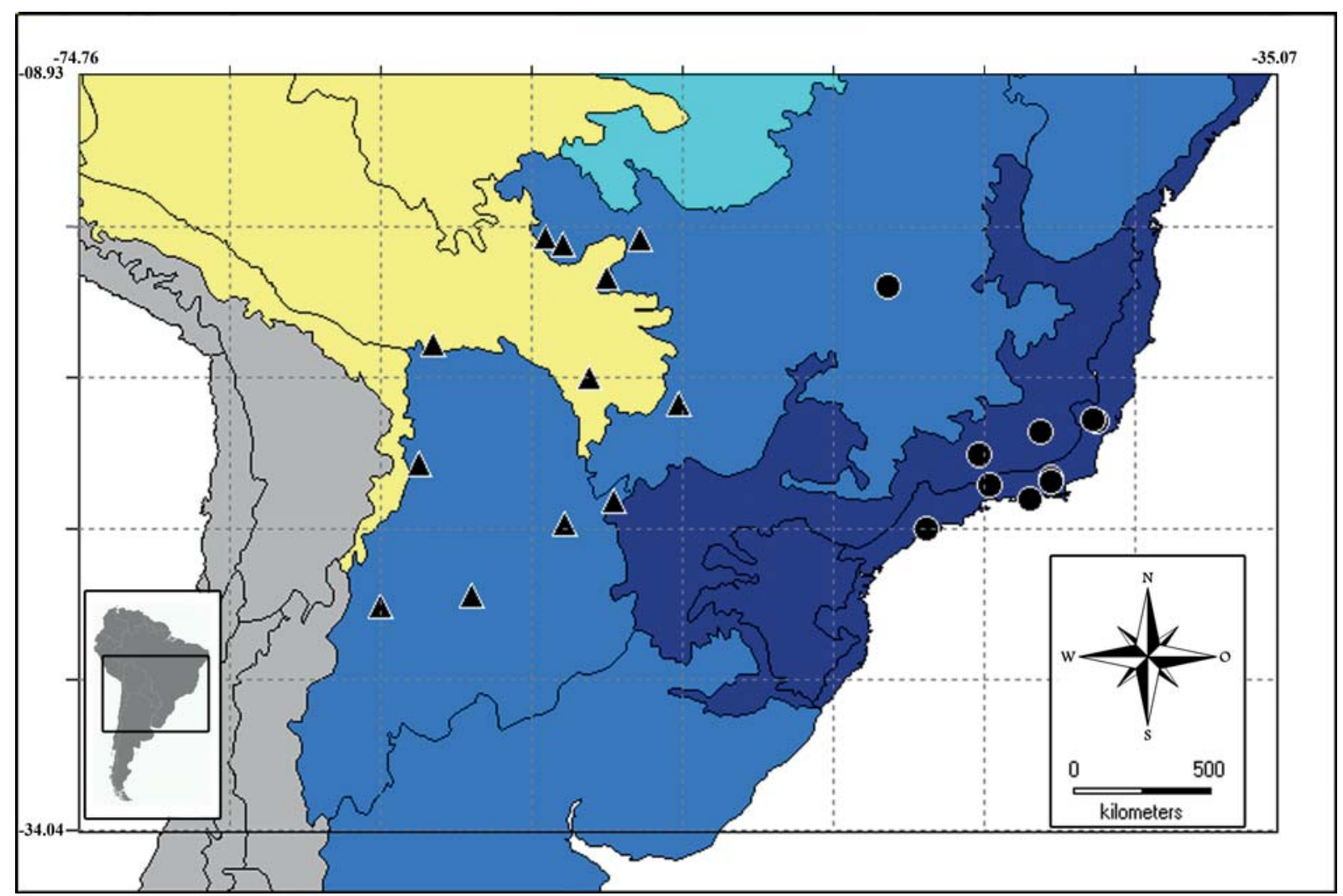

Fig. 10. Geographical distribution of Canthidium gigas Balthasar, 1939 (circles) and Canthidium bokermanni (Martínez et al., 1964) (triangles).. 
no other specimens have been reported from that region. Furthermore, the German entomologist Carl Felsche (who acquired the specimen) was known for buying insects, and this kind of mislabelling has been seen before with his specimens (FZVM, personal observation).

Canthidium (Neocanthidium) bokermanni (Martínez et al., 1964)

Figs 3, 10

Neocanthidium bokermanni Martínez et al., 1964: 168-172 (original description).

Neocanthidium bokermanni - Solís \& Kohlmann 2004: 5 (checklist). — Kohlmann \& Solís 2006: 236 (checklist). - Cupello 2018: 453, 465, 467 (checklist).

Canthidium (Canthidium) bokermanni - Martínez \& Halffter 1986: 21 (checklist).

Canthidium bokermanni - Nunes \& Vaz-de-Mello 2013: 416 (mention).

Canthidium (Neocanthidium) bokermanni - Cupello 2018: 467 (new subgeneric assignment).

Dichotomius (Luederwaldtinia) paraguayanus Gandini \& Aguilar, 2009 (parts): 139, figs 1-8 (2 paratypes).

\section{Type material examined}

\section{Holotype}

ARGENTINA • Ō; handwritten label; "ARGENTINA, TUCUMAN, Dto BURRUYAÇÚ/ Km. 5 Burruyaçu/a San Ramón/ Coll. Martínez// 28-III-946"; "HOLOTYPUS"; "Neocanthidium/ bokermanni/ M., H. y P sp. n. §̋/ A. MARTÍNEZ DET.1963”; "MACN-En 903”; MACN.

\section{Paratypes}

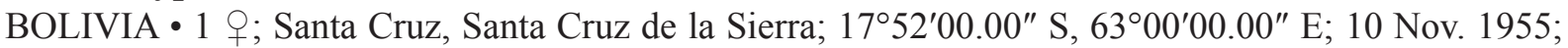
R. Zischa leg.; CEMT.

\section{Dichotomius paraguayanus}

\section{Paratypes}

PARAGUAY • 1 ð̊; Concepción, Zanja Morotí; 17 Nov. 2001; Martínez leg.; CEMT • 1 đ̊; Boquerón, Loma Plata; 24 Sep. 1995; Drechsel leg.; CEMT.

\section{Other specimens examined}

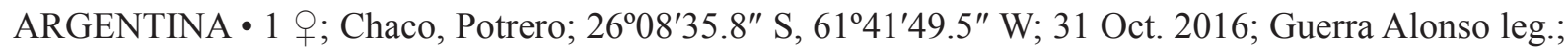
CEMT.

BOLIVIA - 1 đ; Santa Cruz, Germán Busch, Puerto Suárez, Cerro de Mutum; $18^{\circ} 58^{\prime} 00^{\prime \prime}$ S, 57²7'53.00" E; Dec. 2012; P. Wagner leg.; CEMT • 1 q; Tarija, between Caiza and Crevaux; blue light; $21^{\circ} 48^{\prime} 53^{\prime \prime}$ S, 6326'53" W; 536 m a.s.1.; 5 Jan. 2005; Mann, Hamel and Herzog leg.; OUMNH.

BRAZIL • 1 q; Mato Grosso, Cuiabá; 8 Mar. 2016; L.P. Melo leg.; CEMT • 1 q; Chapada dos Parecis, 30 km N Uirapuru; FIT; $14^{\circ} 17^{\prime}$ S, 59¹5' W; 1-15 Dec. 2001; A. Foucart leg.; CEMT • 1 q; Diamantino, Vale da Solidão, riparian Forest; $14^{\circ} 21^{\prime} 50^{\prime \prime}$ S, 56 $6^{\circ} 7^{\prime} 23^{\prime \prime}$ W; 18 Feb. 2009; D.T.C. Oliveira leg.; CEMT $\bullet 1$ \%; same locality as for preceding; 26 Jan. 2009; D.T.C. Oliveira leg.; CEMT • 1 क ; same locality as for preceding; $14^{\circ} 21^{\prime} 52^{\prime \prime}$ S, 56 $6^{\circ}{ }^{\prime} 23^{\prime \prime}$ W; 23 Dec. 2008-26 Jan. 2009; D.T.C. Oliveira leg.; CEMT • 1 क; same locality as for preceding; $14^{\circ} 22^{\prime} 23^{\prime \prime}$ S, 56 $6^{\circ} 25^{\prime \prime}$ W; 31 Jan.-14 Feb. 2009; D.T.C. Oliveira leg.; CEMT • 1 O; Porto Estrela, Estação Ecológica ["Est. Eco"] Serra das Araras; light trap; 15³9'14" S, 57¹3'1" W; Nov. 2003; L. Kaminski leg.; CEMT • 1 क; same locality as for preceding, Boca do José;

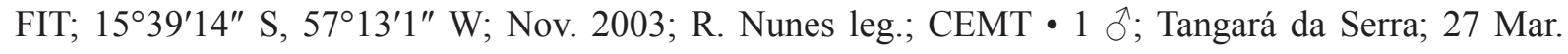


2016; G.A.A. Arenhart leg.; BMNH • 2 + ; Tangará da Serra, Chácara Asa Branca; manual collection; 14³2'42" S, 5840'28" W; Nov. 2011; E. Meurer leg.; CEMT • 1 क; Tangará da Serra, Campus UNEMAT; light trap; $14^{\circ} 38^{\prime} 58^{\prime \prime}$ S, 57 $57^{\circ} 5^{\prime} 24^{\prime \prime}$ W; 439 m a.s.l.; R.J. Silva leg.; CEMT • 1 q ; Chácara Paraíso, semideciduous forest; FIT; $14^{\circ} 39^{\prime} 4^{\prime \prime}$ S, 57 $7^{\circ} 4^{\prime} 55^{\prime \prime}$ W; 460 m a.s.1.; 26 Jan. 2011; CEMT • 1 O; same data as for preceding; BMNH -2 ô; Campos de Júlio, Chapada dos Parecis, $30 \mathrm{~km}$ N of Uirapuru; FIT; $14^{\circ} 17^{\prime}$ S, 59¹5' W; Dec. 2002; A. Foucart leg.; CEMT • 1 q; Cuiabá; 8 Mar. 2016; P.L. Mello leg.;

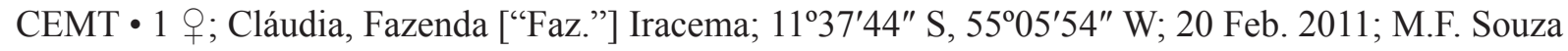

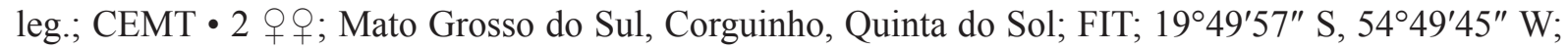
Feb. 2011; L.O. Bavutti leg.; CEMT.

\section{Diagnosis}

Canthidium bokermanni resembles C. gigas in the presence of a transverse carina on the head and distinct punctation of the pronotal disc; it differs only in the dorsal angles of the parameres. See comments under C. gigas for more details.

\section{Redescription}

HEAD. Surface with dense and distinctly punctation, especially on clypeus. With a transverse raised projection in the front.

Pronotum. Without anteromedial depression, disc anteriorly convex, sometimes with an anterior sinuosity forming two broad and shallow depressions (both surrounding the medial line).

Hypomeron. With microstriae and setae in the basal part. Hypomeral carina complete, curved throughout its length.

MetaVentRIte. With simple and shallow punctation, laterobasal region with stronger punctation, lateral region with microsculpture obscurely variolate, almost semicircular.

MESEPIMERON AND MESEPISTERNUM. With shallow punctation, stronger microsculpture obscurely variolate, semicircular.

HIND LEG. Metafemora with a carina along posterior edge, anterior edge with setal fringe, surface with fine punctation. Metatibiae elongated and gradually dilated towards the apex; external margin serrated.

AedeAgus. In dorsal view, parameres lacking angulation apically and with a shallow excavation at apex; in lateral view, dorsally with internal median angulation of $160^{\circ}$.

\section{Variation and sexual dimorphism}

Total length ranges from 9 to $13 \mathrm{~mm}$. The transverse carina of the head varies from rectangular to oval, regardless of the size and sex of the specimen. The males have a tooth in the upper ventral part, more developed in some specimens than in others. Males have ventrite VI wider medially, female ventrite VI is of the same length throughout. Males also have protibial spur flattened, while in females the protibial spur is narrowed and pointed.

\section{Geographical distribution}

The specimens examined were collected in Argentina (Chaco), Brazil (Mato Grosso and Mato Grosso do Sul), Bolivia (Santa Cruz), and Paraguay (Concepción and Boquerón). The species occurs in two different biogeographic dominions: the Chacoan dominion and the South Brazilian dominion. 


\section{Comments}

Two paratypes of Dichotomius paraguayanus, which were incorrectly interpreted as females by Gandini \& Aguilar (2009), proved to be males and to belong to C. bokermanni.

\section{Discussion}

As previously stated, species groups have so far been delimited, for practical purposes, in several Scarabaeinae genera including Dichotomius Hope, 1838 (Luederwaldt 1929; Nunes \& Vaz-de-Mello 2013), Onthophagus Latreille, 1802 (Zunino \& Halffter 1997), Eurysternus Dalman, 1824 (Génier 2009), Ontherus Erichson, 1847 (Génier 1996) and Canthon Hoffmannsegg, 1817 (Halffter \& Martínez 1977). We note that the members of the gigas group exhibit unique characters that distinguish them from their congeners. In fact, some authors have identified specimens of the gigas group in other genera [such as Dichotomius (Nunes \& Vaz-de-Mello 2013)], which shows how much they differ from other species of Canthidium.

In addition to the above described morphological characteristics that separate the species, the group is well established based on its geographical distribution. Endemic to South America, the species occurs in different ecoregions. Canthidium gigas and C. ayri sp. nov. are endemic to the Atlantic Forest, their occurrence being restricted respectively to the north and south of this biome. Canthidium bokermanni and C. kelleri are found in Cerrado vegetation; C. bokermanni in the west region of the biome, and C. kelleri in the east. Finally, C. feeri sp. nov. is restricted to French Guiana, north of the Amazon biome, and C. stofeli sp. nov. occurs in the southern region of this biome.

The group also has unique characteristics regarding feeding. Most species of Scarabaeinae are coprophagous, but there may be variations, such as $C$. kelleri and C. bokermanni feeding on the mycelia of fungi (Halffter \& Matthews 1966). Most recently, Falqueto et al. (2005) reported C. gigas from fungus-baited pitfall traps. The two paratypes of $C$. ayri sp. nov. were collected with light traps and the other species often appear in flight interception traps, in addition to traps baited with fungi. More studies and field observations are needed to confirm if fungi are indeed a fundamental part of these species' diet.

\section{Conclusions}

This work dealt with the taxonomic revision of the Canthidium species of the gigas group. We described three new species for the group, but we firmly believe that in order to broaden the distribution data more studies are required, including field collecting and museum studies.

\section{Acknowledgments}

We thank the curators Ayr M. Bello (AMBC), Sonia Casari and Carlos Campaner (MZSP), Darren Mann (OUMNH), Jirí Hajek (NMPC) and Trond Larsen (TLC) for loaning part of the material examined, and Jirí Hajek and Martin Fikacek, Svata (in memoriam) and Petr Pokorný for hosting the third author during his visit to NMPC and Prague. We thank Olivier Boilly and Paolo Gandini for making available and donating the type specimens of Dichotomius paraguayanus. Mario Cupello is thanked for providing photographs of the holotypes of Canthidium bokermanni and C. kelleri housed at MACN. We are grateful also to Mario Cupello, Renato Machado, Paul Skelley, François Génier and anonymous reviewers for critically reading the manuscript and suggesting several improvements, we are grateful also to Maxwell V.L. Barclay for reviewing the English, and the funding agencies that made it possible to carry out this work: Conselho Nacional de Desenvolvimento Científico e Tecnológico (CNPq): 302997/20130; 484035/2013-4; 405697/2013-9; 440604/2015-0; 306745/2016-0; 142383/2017-1; 248299/2012-3; Fundação de Amparo à Pesquisa do Estado de Mato Grosso (FAPEMAT): 568005/2014; 146138/2015; 0147956/2017; ISYEB, UMR 7205 CNR/MNHN; INCT-CENBAM / CNPq; ComCerrado Network / MMA / CNPq; UFMT PIBIC 2014-15. 


\section{References}

Balthasar V. 1939. Neue Canthidium-Arten. (8. Beitrag zur Kenntniss der Scarabaeiden der neotrop. Region). Entomologiches Nachrichtenblatt 13: 111-140.

Boucomont A. 1928. Coprophages d'Amérique du Sud nouveaux ou peu connus. Bulletin de la Société Entomologique de France 12: 186-194, 202-207.

Cupello M. 2018. On the types species of the New World dung beetle genus Canthidium Erichson, 1847 (Coleoptera: Scarabaeidae: Scarabaeinae), with an annotated checklist of species. Zootaxa 4388: 451-486. https://doi.org/10.11646/zootaxa.4388.4.1

Dalman J.W. 1824. Ephemerides Entomologicae. Norstedt, P. A., Holmiae.

Erichson W.F. 1847. Conspectus insectorum coleopterorum quae in Republica Peruana observata sunt. Archiv für Naturgeschichte 13: 67-185.

Falqueto S.A., Vaz-de-Mello F.Z. \& Schoereder J.H. 2005. Are fungivorous Scarabaeidae less specialist. Ecología Austral 15: 17-22.

Gandini P. \& Aguilar C. 2009. Seis nuevas especies de Dichotomius Hope, 1838 (Coleoptera: Scarabaeidae: Scarabaeinae) de Sudamérica y descripción del macho de Dichotomius camargoi Martínez, 1956. Giornale Italiano di Entomologia 12: 135-164.

Génier F. 1996. A revision of the Neotropical genus Ontherus Erichson (Coleoptera: Scarabaeidae: Scarabaeinae). Memoirs of the Entomological Society of Canada 170: 1-169.

https://doi.org/10.4039/entm128170fv

Génier F. 2009. Le Genre Eurysternus Dalman, 1824 (Scarabaeidae: Scarabaeinae: Oniticellini), Révision taxonomique et Clés de Détermination illustrées. Pensoft Publishers, Sofia.

Génier F. \& Cupello M. (2018) Canthidium alvarezi Martínez \& Halffter, 1986: a remarkable Ateuchus Weber, 1801 (Coleoptera: Scarabaeidae: Scarabaeinae). Insecta Mundi 646: 1-4.

Halffter G. \& Martínez A. 1977. Revisión monográfica de los Canthonina americanos, IV parte. Clave para géneros y subgéneros. Folia Entomológica Mexicana 38: 29-107.

Halffter G. \& Matthews E.G. 1966. The natural history of dung beetles of the subfamily Scarabaeinae (Coleoptera, Scarabaeidae). Folia Entomológica Mexicana 12-14: 1-132.

Harold E. von. 1867a. Zur Kenntniss der Gattung Canthidium und ihrer nächsten Verwandten. Coleopterologische Hefte 1: 1-61.

Harold E. von. 1867b. Nachtrag zur Bearbeitung der Gattung Canthidium. Coleopterologische Hefte 2: 60-93.

Harris R.A. 1979. Glossary of surface sculpturing. Entomology 28: 31 pp.

Hoffmannsegg G. von. 1817. Entomologische Bemerkungen bei Gelegenheit der Abhandlungen über amerikanische Insecten, in der vierten bis sechsten Lieferung von den recueils d'observations de zoologie et d'anatomie comparée, oder dem 2ten Theile der Reise, der Herren Al. v. Humboldt und A. Bonpland, nemlich: No. IX. in Livr. 4. p. 197-283. und No. XI. XII. in Livr. 5. 6. p. 294-397. Zoologisches Magazin 1: 8-56.

Hope F.W. 1838. Observations on the Lamellicorns of Olivier. Entomological Magazine 5: 312-326.

Howden H.F. \& Young O.P. 1981. Panamanian Scarabaeinae: taxonomy, distribution, and habits (Coleoptera, Scarabaeidae). Contributions of the American Entomological Institute 18: 1-204. 
Kohlmann B. \& Solís A. 2006. El género Canthidium (Coleoptera: Scarabaeidae) en Norteamerica. Giornale Italiano di Entomologia 11: 235-295.

Latreille P.A. 1802. Histoire Naturelle générale et particulière des Crustacés et des Insectes. Ouvrage faisant suite à l'Histoire générale et particulière, composée par Leclerc de Buffon, et rédigée par C.S. Sonnini, membre de plusieurs Sociétés savantes. Familles naturelles des Genres, Tome troisième. F. Dufart, Paris.

Löwenberg-Neto P. 2014. Neotropical region: a shapefile of Morrone's (2014) biogeographical regionalization. Zootaxa 3802: 300-300. https://doi.org/10.11646/zootaxa.3802.2.12

Luederwaldt H. 1929. As especies brasileiras do genero Pinotus. (Coleoptera - Lamellicornidae Coprini), com algumas considerações tambem sobre outras especies. Revista do Museu Paulista 16: 603-775.

Martínez A. 1947. Addenda y corrigenda al trabajo de Blackwelder 'Checklist of the coleopterous insects of Mexico, Central America, the West Indies, and South America (Scarabaeidae, Coprine)'. Arthropoda 1: 109-114.

Martínez A. \& Halffter G. 1986. Situación del género Canthidium Erichson (Coleoptera: Scarabaeidae: Scarabaeinae). Acta Zoológica Mexicana 17: 19-40.

Martínez A., Pereira G. \& Halffter E. 1964. Notes on the genus Canthidium and allied genera. Studia Entomologica 7: 161-178.

Morrone J.J. 2014. Biogeographical regionalisation of the Neotropical region. Zootaxa 3782: 1-110. https://doi.org/10.11646/zootaxa.3782.1.1

Nunes R.V. \& Vaz-de-Mello F.Z. 2013. New brachypterous species of Dichotomius Hope, with taxonomic notes in the subgenus Luederwaldtinia Martínez (Coleoptera: Scarabaeidae: Scarabaeinae). Zootaxa 3609: 411-420. https://doi.org/10.11646/zootaxa.3609.4.3

Solís A. \& Kohlmann B. 2004. El género Canthidium (Coleoptera: Scarabaeidae) en Costa Rica. Giornale Italiano di Entomologia 11: 1-73.

Vaz-de-Mello F.Z. 2000. Estado atual de conhecimento dos Scarabaeidae s. str. (Coleoptera: Scarabaeiodea) do Brasil. In: Martín-Piera F., Morrone J.J. \& Melic A. (eds) Hacya un proyecto CYTED para el inventario y estimación de la diversidad entomológica en Iberoamérica: PRIBES-2000. m3m: Monografias Tercer Milenio. Vol. 1: 183-195. Sociedade Entomológica Aragonesa, Zaragoza.

Vaz-de-Mello F.Z., Edmonds W.D., Ocampo F.C. \& Schoolmeesters P. 2011. A multilingual key to the genera and subgenera of the subfamily Scarabaeinae of the New World (Coleoptera: Scarabaeidae). Zootaxa 2854: 1-73.

Vulcano M.A. \& Pereira F.S. 1964. Catalogue of the Canthonini (Col. Scarab.) inhabiting the Western Hemisphere. Entomologische Arbeiten aus dem Museum G. Frey 15: 570-685.

Zunino M. \& Halffter G. 1997. Sobre Onthophagus Latreille, 1802 americanos (Coleoptera: Scarabaeidae: Scarabaeinae). Elytron 11: 157-178.

Manuscript received: 24 December 2018

Manuscript accepted: 16 April 2019

Published on: 6 June 2019

Topic editor: Gavin Broad

Desk editor: Eva-Maria Levermann 
Printed versions of all papers are also deposited in the libraries of the institutes that are members of the EJT consortium: Muséum national d'Histoire naturelle, Paris, France; Meise Botanic Garden, Belgium; Royal Museum for Central Africa, Tervuren, Belgium; Royal Belgian Institute of Natural Sciences, Brussels, Belgium; Natural History Museum of Denmark, Copenhagen, Denmark; Naturalis Biodiversity Center, Leiden, the Netherlands; Museo Nacional de Ciencias Naturales-CSIC, Madrid, Spain; Real Jardín Botánico de Madrid CSIC, Spain; Zoological Research Museum Alexander Koenig, Bonn, Germany; National Museum, Prague, Czech Republic. 